\title{
Working
}

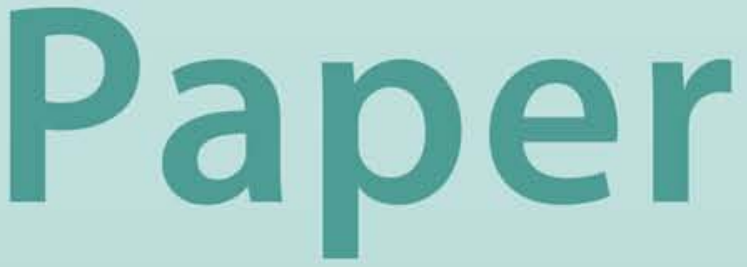




\section{Growth from International Capital Flows: The Role of Volatility Regimes}

Ashoka Mody and Antu Panini Murshid 


\title{
IMF Working Paper
}

European Department

\section{Growth from International Capital Flows: The Role of Volatility Regimes}

\section{Prepared by Ashoka Mody and Antu Panini Murshid ${ }^{1}$}

Authorized for distribution by the European Department

April 2011

\begin{abstract}
Recent commentary has downplayed the growth dividend from international financial integration, highlighting the possibly negative correlation between capital inflows and long-run growth. This paper presents new evidence consistent with standard economic theory and a more benign interpretation of cross-border private capital flows. The key observation is that a country's growth volatility changes over time. With volatility below a threshold, an inflow of foreign capital has promoted growth. However, during periods of volatile growth, more flows have been associated with slower growth. Volatility levels and changes reflect an interaction of domestic production and institutional structures with global factors.
\end{abstract}

\section{JEL Classification Numbers: F43}

Keywords: Capital flows, growth, growth volatility, heteroscedasticity, volatility regimes

Author’s E-Mail Address: amody@imf.org; amurshid@uwm.edu

\section{This Working Paper should not be reported as representing the views of the IMF.}

The views expressed in this Working Paper are those of the authors and do not necessarily represent those of the IMF or IMF policy. Working Papers describe research in progress by the authors and are published to elicit comments and to further debate.

\footnotetext{
${ }^{1}$ The authors are grateful to Alexandra Tabova and Jon Temple for sharing data and to Michael Bordo, Stijn Claessens, Charles Engel, Sebnem Kalemli-Ozcan, Damiano Sandri, Jon Temple and Thierry Tressel for helpful feedback.
} 


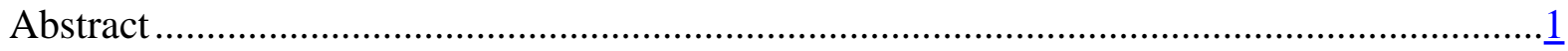

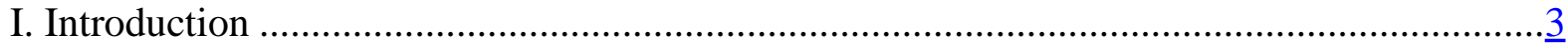

II. Specifying the Growth-Capital Flows Relationship......................................................

A. Dealing with Heteroscedasticity Reveals Misspecification ...................................

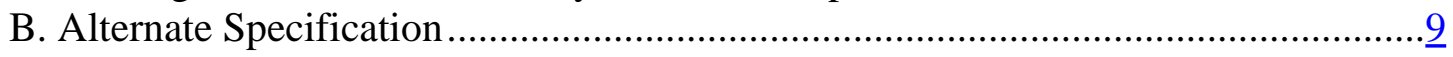

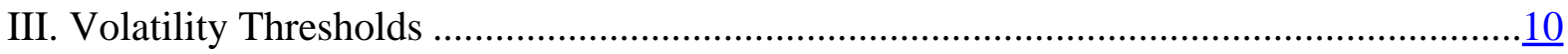

IV. Panel Regressions and Endogeneity ...............................................................

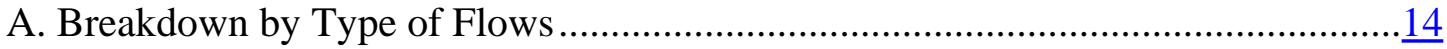

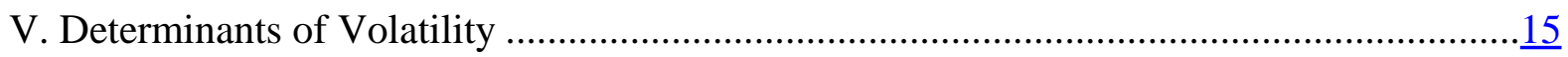

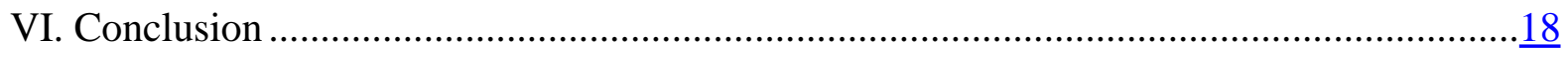

Tables

1. Cross-Country Current Account-Growth Relationship in Developing Countries ...............28

2. Current Account-Growth Relationship in Developing Countries: Weighted Regressions..름

3. Within and Between Country Variation in Volatility ..................................................

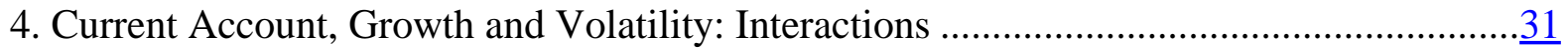

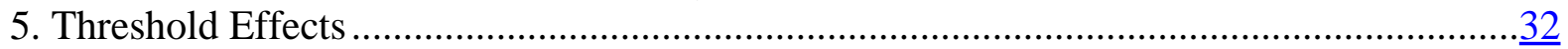

6. Descriptive Statistics by Regime ..............................................................................

7. Current Account Growth Relationship in Countries by Incidence of High Volatility ......... $\underline{34}$

8. Panel Regressions .......................................................................................... $\frac{35}{36}$

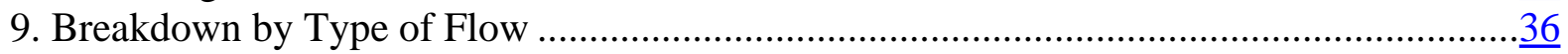

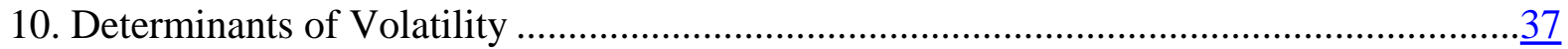

Figures

1. The Paradox of Capital ............................................................................................

2. Current Account and Growth: Volatility Regimes ......................................................

3a. Number of Times Countries Experienced High Growth Volatility ..................................40

3b. Number of Times Countries Experienced High Growth Volatility by Time Period ..........41

Appendix

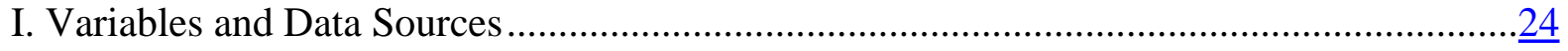

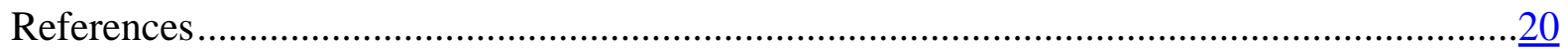




\section{INTRODUCTION}

Developing countries, being short of capital by definition, stood to benefit from the large flows of international capital that came online in the 1980s and 1990s. But apparently that did not happen. In their survey, Kose et. al. (2006) find little robust evidence for long-run growth benefits from global capital inflows. They suggest that international financial integration brings collateral benefits - greater financial development and better macroeconomic policies_-but these do not necessarily or immediately translate into superior growth outcomes. Prasad et. al. (2006) go one step further. They emphasize the negative correlation between growth and capital flows in developing countries, and conclude that international capital may even hurt economic growth in poor countries. Figure 1, which shows that a larger current account surplus (capital outflow) is associated with higher growth, illustrates their point. This "stylized fact" is now the cornerstone of a growing theoretical literature (Gourinchas and Jeanne, 2007; Alfaro et. al., 2008; Devereux and Sutherland, 2009; Sandri, 2010). ${ }^{2}$

Yet some are not persuaded by the emerging consensus. They seek to identify the conditions that generate social value in moving capital from rich to poor countries. Eichengreen (2007, p. 1) has remarked, “...capital flows are something about which it is especially hard to make unconditional statements.” The effectiveness of capital flows may increase steadily with some conditioning characteristic: for example, Arteta et. al. (2003) conclude that greater policy reform allows more gains from capital account liberalization. Alternatively, the effectiveness of inflows may increase discretely beyond certain conditioning thresholds. The search for such nonlinearities, however, has been elusive, as Kose et. al. (2009, p. 9) conclude: “The empirical literature has reported many interesting results but the robustness of these results and the estimated thresholds vary widely.” From their own research, no decisive thresholds emerge. They do conclude that institutional quality and financial development are most likely to promote productive use of foreign capital.

We make three contributions to promote the thresholds' research agenda. First, growth volatility is a robust threshold variable. Second, sharper results are obtained by distinguishing country regimes instead of merely differentiating countries, as is the usual practice. In the low volatility regime, the positive relationship predicted by standard economic theory is clear; this disappears in the high-volatility regime. ${ }^{3}$ These findings support Pritchett (2000) and Jerzmanowski (2006)

\footnotetext{
${ }^{2}$ China as the example for high growth with capital outflows is misleading because Chinese growth is well above the norm implied by the regression line (the same is true of other East Asian economies, Korea and Malaysia). This reflects a variety of factors that have contributed to the extraordinary Chinese growth. When that extraordinary dimension is controlled for, China's growth is higher with capital inflows, as we show below.

${ }^{3}$ Sandri (2010) develops a model where countries facing financial frictions (and therefore high volatility) grow by increasing precautionary savings and running current account surpluses, while countries with developed financial markets (which experience less volatility) grow by running current account deficits. Thus the model has similar implications for the relationship between the current account, growth and volatility, although the causality runs from exogenous growth opportunities to the current account, rather than the other way around.
} 
who show that countries fall in and out of regimes, with distinct changes in the nature and determinants of growth. Conflating regimes is, therefore, potentially misleading. Finally, shifts in a country's growth volatility are primarily the outcome of external factors.

There are good reasons to expect that high volatility periods will be associated with smaller foreign capital inflows and their growth effects. The greater uncertainty is likely to deter investors, reducing, as we find, the inflows of private capital. When volatility is high, investment in equipment and technology will tend to be deferred with greater planning errors. ${ }^{4}$ Higher macroeconomic volatility also depresses complimentary investment in human capital (Krebs et. al., 2010). Thus, regime shifts change both the extent of capital inflow and their productivity. The implication also is that the "long-term" effects of capital flows for an individual country are not precisely defined where countries do not stay in the same regime.

Using growth over five-year periods as the unit of observation, volatility (the standard deviation of growth) varies between a low of 0.27 percent and a high of 25.65 percentage points, similar to the range observed by Ramey and Ramey (1995). On the basis of Hansen (1996 and 2000), we find that a GDP growth volatility of 5.35 percent distinguishes low and high volatility regimes. Of our core sample of 61 countries, 59 were in the low volatility regime for at least one of the five-year periods covered by our analysis, 1980-2003; 35 were in the high volatility regime for at least one period.

With that set up, we separately analyze the determinants of growth for observations in the low and high volatility regimes. We conclude that the finding of no relationship between capital inflows and growth is driven principally by the breakdown of that relationship in high volatility regimes. In contrast, when countries are in the lower volatility zone, they receive capital flows largely in the form of private capital and these higher inflows are, in fact, associated with higher growth. This relationship holds in the cross-section and in GMM models that potentially account for endogeneity. Interestingly, the aggregate capital inflows/GDP ratio has not necessarily been lower in the high volatility regime: rather, in high volatility regimes, capital arrives mainly in the form of official aid, which (as Deaton, 2010 summarizes) is not associated with higher growth.

Much of the empirical literature on capital flows-growth performance has focused on institutional quality as the differentiating variable. However an analysis based on threshold regressions suggests that capital inflows are not necessarily more effective in countries with stronger institutions. This finding is initially puzzling, since volatility has been linked to the quality of institutions (Acemoglu et. al., 2003). But it helps to note that while volatility changes significantly over time, institutions do not. Hence, institutions are less able to track regime

\footnotetext{
${ }^{4}$ Across countries, high volatility is associated with lower growth (Ramey and Ramey, 1995, and Burnside and Tabova, 2010). Jerzmanowski (2006) finds this inverse relationship over time within a country. Similarly Zarnowitz and Moore (1986) report that periods of low growth in the United States have been marked by higher volatility. Bachmann et. al. (2010), using U.S. and German data, find that increased uncertainty is associated with mediumterm reductions in manufacturing output and employment.
} 
changes within a country. Our results show that the quality of institutions is just one of a constellation of factors that combine to determine the overall volatility in a country. A country's volatility arises from the interaction of its location and institutional features with global factors. Location is associated with production diversity, creating varying degrees of potential volatility (Malik and Temple, 2009). Conditional on these country characteristics, the level and changes in volatility are the consequence of factors external to a nation, including US interest rates and commodity prices (Burnside and Tabova, 2010). Volatility-and with it the effectiveness of capital inflows - can thus change for exogenous reasons.

The remainder of this paper is organized as follows. To persuade the reader that our results are not the outcome of a particular sample or methodology, in Section 2, we trace the evolution of results from the benchmark regression of Prasad et. al. (2006) through variations that highlight the role of volatility. We conclude that a pooled cross-country regression misspecifies the capital inflows-growth relationship. In particular, as distinct from standard OLS, maximum likelihood estimates support a strongly positive role for capital inflows. This occurs because maximum likelihood estimates place lower weight on high growth-volatility observations, reducing their influence in the determination of the coefficients. But since maximum likelihood is expected to increase efficiency and not correct for bias, we interpret the difference between the OLS and maximum likelihood results to signal a misspecification.

The intuition for this statistical finding is developed in Section 3 by identifying a volatility threshold that differentiates two regimes: one where volatility is low and foreign capital is productive, and one where it is high and foreign capital has little growth impact. We also report that conventional distinctions between good and bad institutions do not differentiate the productivity of international capital. In Section 4, GMM results are used to address the endogeneity concern. Here we also report results for private and official flows. The distinction between low and high volatility regimes continues to be robust.

In Section 5, we examine the determinants of growth volatility, based on two recent papersMalik and Temple (2009) and Burnside and Tabova (2010). The analysis identifies structural characteristics that are important for understanding cross-country differences in volatility. Conditional on these characteristics, growth volatility is a function of external drivers, which are largely exogenous. Section 6 concludes. 


\section{SPECIFYING THE GROWTH-CAPITAL FLOWS RELATIONSHIP}

The empirical basis for the capital flows-growth relationship is the standard cross-country growth equation:

$$
g_{i}=x_{i}^{\prime} \beta+\theta k_{i}+\varepsilon_{i}
$$

Here $g_{i}$ is the average long-run growth rate of real GDP per capita in country $i, x_{i}$ is a set of controls, and $k_{i}$ is a measure of the average capital inflow in country $i$. In Prasad et. al. (2006) this measure of capital flows is the size of the current account surplus. When countries run a current account surplus, they export capital and when they run a deficit, they receive foreign capital to finance that deficit. Foreign capital inflows may take the form of private investment, portfolio equity, or credit flows; supplemented by loans from official agencies. The controls for other growth determinants are the usual suspects - initial income, life expectancy, trade openness, fiscal balance, and institutional quality.

We begin by trying to reproduce the Prasad et. al. (2006) findings before considering a number of extensions. Since a current account surplus measures an outflow of capital, a positive coefficient on the current account implies that larger outflows are associated with higher growth. There are two main differences between our replication effort and the Prasad et. al. (2006) baseline. First, we focus on a 24-year period from 1980 to 2003, while they covered the period 1970-2000; we omit their first ten years since the emergence of sizeable global capital flows is a characteristic of the post-1980s. Second, we increase country-coverage by measuring openness using the volume of trade (exports plus imports normalized by GDP) as opposed to the Sachs and Warner dummy. Thus, while our coefficient on openness is not directly comparable with theirs, all other coefficient estimates are, including that on the current account. The data sources are listed in the Data Appendix (Table A.1).

Column 1 in Table 1 reports the Prasad et. al. (2006) results and column 2 reports our version of their specification. The comparable coefficients are of similar magnitudes, differences in statistical significance notwithstanding. They find that a decline in the current account-to-GDP ratio of one percent (i.e. an increase in the capital inflows-to-GDP ratio) is associated with a 0.1 percentage point drop in the average annual growth rate. From this they conclude that capital inflows hurt rather than help growth. Although with a smaller t-statistic, we find a coefficient of 0.06, supporting their result.

The adverse relationship between capital flows and growth is particularly characteristic of heavily aid-dependent countries, which are developmentally weak (Deaton, 2010). In column 3, we omit countries where the average aid flows exceeded ten percent of GDP. That brings the sample down from 87 to 61 countries (see Table A.2, Data Appendix), and the significance of the current account coefficient disappears. Yet, while capital flows no longer appear detrimental to growth, they do not appear to promote growth either. 


\section{A. Dealing with Heteroscedasticity Reveals Misspecification}

Typically, when estimating cross-country growth regressions, the average growth rate over the entire period is regressed against initial values or averages of covariates. But is averaging necessary for identifying long-run relationships and is it the most efficient use of data? When the data are heteroscedastic, the answer is "no." Growth datasets are panels, providing a time dimension (as well as one that spans countries), and therefore a basis exists for estimating the heteroscedasticity in the errors. It is surprising then that OLS and not GLS is the standard econometric framework for growth-analysis.

A notable exception to the common approach is the important contribution by Ramey and Ramey (1995). In their study on the link between output volatility and growth, volatility matters not only because it is a determinant of long-run growth, but also because it suggests scope for improving estimation efficiency. To this end, they regress annual growth rates against a set of countryspecific growth determinants using a maximum likelihood procedure that simultaneously exploits the time series variation in growth (to estimate growth volatility) as well as the crosscountry variation in explanatory variables.

We adapt the Ramey and Ramey (1995) framework to estimate the following model:

$$
\begin{aligned}
& g_{i, t}=x_{i}^{\prime} \beta+\theta k_{i}+\varepsilon_{i, t} \\
& \varepsilon_{i, t} \sim N\left(0, \sigma_{i, j}\right)
\end{aligned}
$$

where $g_{i, t}$ is the annual growth rate in country $i$ for $i=1,2, \ldots .61$ at time $t$ for $t=1980$, $1981, \ldots, 2003$. The explanatory variables retain their cross-sectional nature: hence the growth determinants, $x_{i}$, vary only across countries, and, thus, $k_{i}$ is the average size of the current account balance for country $i$. The innovations to growth, $\varepsilon_{i, t}$, are assumed to be normally distributed with mean zero and standard deviation, $\sigma_{i, j}$, which, as in Ramey and Ramey (1995), varies across countries but-distinctively in our case-also over time. We allow for five nonoverlapping time intervals: $j=1980-84,1985-89,1990-94,1995-99$, and 2000-03. Volatility is allowed to change from one interval to another but stays the same within each interval. The assumption of normality is not essential; however, it allows us to estimate equations (2a) and (2b) jointly using maximum likelihood. ${ }^{5}$

To help the reader appreciate the evolution of the results, we present these in a number of steps in columns 4 through 6 . With 24 observations for each country, there are now 1,464 observations in total. Although the dependent variable varies from year to year, the variation in the independent variables is purely cross-sectional hence OLS yields identical coefficients to those

\footnotetext{
${ }^{5}$ Alternatively we could estimate (2a) using iterated feasible GLS. Since the parameter estimates are not sensitive to the method of estimation, we report only our results based on MLE.
} 
reported in column 3 (where the dependent variable is the average growth rate for each country). ${ }^{6}$ However, in this case the standard errors will in general be biased downward, making a correction for clustering (by country groups) necessary. The resulting corrected standard errors in column 4 are smaller than in column 3, although only marginally. In columns 5 and 6, we present the maximum likelihood estimates as in Ramey and Ramey (1995), i.e., allowing volatility to vary only across countries. Now, the sign on the coefficient on the current account balance, suggestively, does change. However, the relationship appears little more than statistical noise. Note that our results are consistent with Ramey and Ramey's finding that higher volatility is associated with lower growth.

The important departure is in Table 2 where we estimate the system 2(a)-(b) allowing volatility to vary not only across countries but also over five-year intervals. In column 1 , the covariates are retained as country averages or initial values. The coefficients on income, life expectancy, trade openness and institutional quality are comparable to the earlier regressions. The effect of the current account, however, is very different: the negative coefficient has a larger absolute size and is marginally significant at the 10 percent level. In columns 2 to 4 , the covariates also vary over five-year periods, ${ }^{7}$ thus the emphasis shifts from a long-run to a medium-term analysis of growth. In these specifications, capital inflows show a strong relationship with higher growth, one that is significant at the conventional 5-percent level. Thus capital inflows may actually help, as the simplest economic theory leads us to expect.

But why are these results so different from those of Prasad et. al. (2006)? Two aspects of our approach generate these differences: estimation by maximum likelihood and allowing for timevarying volatility. In maximum likelihood estimation, each observation is weighted by the reciprocal of volatility. Such a transformation should generate efficiency gains since high volatility episodes, which contain less information, are rendered less influential. It is unlikely, however, that efficiency gains can explain the large difference between the coefficient estimates. Notice, for example, that the other explanatory variables do not change sign, always retain their statistical significance, and change modestly in quantitative terms through the various exploratory exercises. It is only the current account coefficient that changes steadily from positive to negative (and significant). Thus, we might conjecture that the models relating capital flows and growth are misspecified, which, in turn, imparts a bias to the estimates. In particular,

\footnotetext{
${ }^{6}$ This is by construction. The regression using pooled annual data can be thought of as two separate regressions; in the first step, for each country $i$, we minimize the within sum of squared errors and in a second step we minimize the between group sum of squared errors. Because our controls exhibit no within country variation, the first stage is, in effect, a regression of the annual growth rate, $y_{i}$, against a constant, such that, $\hat{y}_{i}=\bar{y}_{i}$ for each $i$, which means that in the second step we would simply be regressing the mean growth rate in each country (the fitted value from the first step) against our controls.

${ }^{7}$ Since the institutional quality index (taken from Hall and Jones, 1999) is measured around 1985, this variable is unchanging over time. Also, due to the paucity of annual fiscal-balance data, we use a country average for this variable. Thus both our measures of institutional quality and fiscal imbalances are country-specific and do not exhibit any variation over time.
} 
these results suggest that the relationship between the current account and growth is a function of the volatility of growth. Hence, an estimator that places more weight on observations for which the conditional variance of growth is low will tend to isolate a relationship that only holds during those country-periods.

Moreover, volatility can change significantly within countries. This is evident from between- and within-country breakdowns of volatility reported in Table $3 .^{8}$ If volatility is time varying and if a positive relationship between capital flows and growth only holds when volatility is low, then a division of the sample along country lines will not isolate the capital flows-growth relationship. This is evident from maximum likelihood regressions (Table 1, columns 5 and 6) where we allow volatility to vary only across countries. Some countries receive greater weight, while others with higher average volatility receive lesser weight. The relationship between capital flows and growth is not revealed precisely because capital does not always have a beneficial growth impact in a particular country. This contrasts sharply with the results in Table 2, where volatility is allowed to vary over time and the coefficient on the current account is negative and significant.

To be sure, the inference from the above exercise should not be about the appropriate methodology. Rather the findings are suggestive that the specification of the growth equation is suspect. In particular time-varying volatility should belong in this equation as a variable that conditions the impact of capital flows.

\section{B. Alternate Specification}

If the issue is one of misspecification, then re-specifying the model to account for the variation in the relationship between the current account and growth should yield consistent results, even when the method of estimation is OLS. Below we take this approach. In particular, we regress the average growth rate, $g_{i, j}$, in country $i$ in period $j$ (for $j=1980-84,1985-89,1990-94$, 199599, and 2000-03) against average and initial values of our controls, the average size of the current account, $k_{i, j}$, as well as a measure of volatility, $\sigma_{i, j}$, and a term that interacts the current account with volatility. The measure of volatility is obtained from the model estimated in column 4 in Table 2. The results are presented in Table 4.

Simply interacting the current account with growth-volatility does not reveal a statistically meaningful relationship (column 1). This could be because the proper specification of the interaction may be nonlinear. Hence, in columns 2 to 4, we consider interactions between the average size of the current account balance and dummies for whether volatility lies below the

\footnotetext{
${ }^{8}$ For developing countries, Burnside and Tabova (2009) find that external factors (such as U.S. GDP growth, the U.S. interest rate, and commodity prices) account for about 70 percent of GDP fluctuations in developing economies. Since these external factors have a high degree of time variation, it stands to reason that country volatility will also be time-varying. For developed economies, Zarnowitz and Moore (1986) and, more recently, Bachmann et. al. (2010) also find such time variation.
} 
$25^{\text {th }}$ percentile (column 2), below the $50^{\text {th }}$ percentile (column 3 ) and below the $75^{\text {th }}$ percentile (column 4). Our results suggest that when volatility is high, the capital flows-growth relationship is weaker. This differentiation is most evident when the top quartile (the highest 25 percent volatility outcomes) is contrasted with the bottom three quartiles. For the top quartile, growth is positively correlated with the current account, i.e. countries exporting more capital grow faster (a one-percentage point increase in the capital inflows-GDP ratio is associated with 0.16 percentage points lower growth). However, countries in the bottom three quartiles benefit from additional flows: a one percent point increase in the capital inflows-to-GDP ratio is translates into a growth rate that is 0.07 percentage points higher (Table 4 , column 4). The relevant coefficients are significant at the 7-8 percent confidence level rather than the conventional 5 percent level.

In sum, the evidence presented in this section leads to two significant considerations. First, timevarying volatility conditions the relationship between capital flows and growth. Second, the variation in volatility is particularly germane when volatility exceeds a (relatively high) threshold: volatility must be in the top quartile to influence that relationship, but then it does so in a significant way. These results are consistent with threshold effects in the current accountgrowth-relationship, though they are not based on a formal statistical test for such a hypothesis. In the next section, we provide a more rigorous treatment of threshold effects.

\section{VOLATILITY THRESHOLDS}

To test if the capital flows-growth relationship is characterized by threshold effects in volatility, we estimate the following nonlinear growth model:

$$
g_{i, j}=x_{i, j}^{\prime} \beta+\theta_{1} k_{i, j}\left[1-I\left(\sigma_{i, j}>\tau\right)\right]+\theta_{2} k_{i, j}\left[I\left(\sigma_{i, j}>\tau\right)\right]+\varepsilon_{i, j}
$$

This specification allows the effect of the current account, $k_{i, j}$, on growth, $g_{i, j}$, to vary with growth-volatility, $\sigma_{i, j}$. As before, the subscript $i$ indexes countries and $j$ denotes one of the following time periods: $j=1980-84,1985-89,1990-94,1995-99$, and 2000-03. $I\left(\sigma_{i, j}>\tau\right)$, is an indicator function that allows the relationship between $g_{i, j}$ and $k_{i, j}$ to change when $\sigma_{i, j}$ exceeds a threshold, $\tau$. Although $\tau$ is unknown it can be estimated (see Hansen, 1996; 2000), however under a null hypothesis of no threshold, $\tau$ is unidentified. Accordingly the distributions of classical test statistics are non-standard. Nevertheless a test of the null can be formed and pvalues can be computed by bootstrap (see Hansen 1996; 2000).

Below we test this null, i.e. the hypothesis $H_{0}: \theta_{1}=\theta_{2}$ against the alternative $H_{a}: \theta_{1} \neq \theta_{2}$. Since our focus is on a threshold in the current account-growth relationship, we have imposed the restriction that other model parameters are constant across regimes. This restriction is in the 
spirit of the empirical results reported above, which show that only the capital inflows-growth relationship changes in a meaningful way with volatility. ${ }^{9}$

The evidence strongly favors a split based on volatility; the null hypothesis is rejected with a pvalue of 0.02. The split occurs when the standard deviation of growth crosses 5.35 percent of real GDP per capita (Table 5). This is a high threshold; only 25 percent of observations belong to this high volatility regime. Since the low- and high-volatility group regressions are jointly estimated with the threshold using OLS, there is now no weighting of observations by time-varying volatility as was the case in our exploratory exercise above. In the low-variance regime, an inflow of capital of one percent of GDP is associated with a 0.094 percent increase in the growth rate. In the high-volatility regime capital inflows accompany a sharp reduction in growth. These results are depicted also in Figure 2. Notice that while China is an "outlier” in cross-sectional regressions, indicating some omitted factors that explain Chinese performance, once these are put into the black box of country fixed-effects, Chinese growth is positively correlated with capital inflows in the low growth-volatility regime and negatively correlated with capital flows in the high volatility regime. Thus, not taking into account China's special growth drivers, leads to misinterpretation of that country's relationship with capital flows.

If instead, we separate countries by an institutional threshold (columns 3 and 4), the coefficient on capital flows is not significant at the 5 percent level in either the low or the high institutions regime. Thus, institutions do not differentiate countries by the productivity of capital flows; indeed there is no statistical basis for rejecting the null (p-value of 0.54). By contrast, the case for a threshold in income is somewhat stronger. In poor countries, with per-capita income less than $\$ 2,350$, capital flows have negative effects on growth; and this relationship is statistically significant. In richer countries, the relationship between capital inflows and growth is unclear. These differences are not sufficiently different to reject the null hypothesis of no threshold in income ( $\mathrm{p}$-value is 0.2 ).

The quality of institutions and average per-capita income are only marginally lower in the high volatility group (see Panel A of Table 6 where we sort the 298 observations (=61 countries*5 periods-7 missing observations) by low and high volatility). A large number of countries fall in both low and high volatility regimes over the 24-year span of our data. Slow-moving variables such as institutions and income do not change with these large volatility movements. While private capital flows are clearly higher in the low volatility regime, total inflows across the

\footnotetext{
${ }^{9}$ We follow Hansen (1999) in constraining the slope coefficients on a subset of the model variables to be the same across the regimes. This focuses attention on the variable of interest, i.e. the current account. Thus any evidence of a threshold is based solely on the additional explanatory power provided when we allow the effect of the current account to change across regimes.
} 
regimes are similar (in fact, aggregate capital flows are somewhat larger in the high volatility regime) because of the size of official flows in the high volatility regime. ${ }^{10}$

Another helpful differentiation of countries is by the number of periods spent in the highvolatility regime (Panel B of Table 6 and Figure 3(a)). In our 61-country sample, 26 countries were in the low volatility regime throughout. Of the other 35 that experienced high volatility for at least one period, Suriname had four periods of high volatility and the Republic of Congo and Zimbabwe experienced high volatility throughout. Thus, the bulk, 32 countries, experienced high volatility in three periods or less. The incidence of high volatility was not disproportionately concentrated in any specific time period (Figure 3(b)).

Countries in a high volatility regime for fewer periods are richer and have better institutions (the exception are countries with only one period of high volatility which perform better on some dimensions than countries with zero periods of high volatility.) As the number of volatility periods increases, the ratio of private capital flows to GDP decreases; with the exception of the last group of three countries with either four or five periods of volatility where private capital flows are rather high. In this group, Suriname and the Republic of Congo, have large commodity-producing sectors that attract sizeable private capital flows. However, their heavy reliance on commodities implies that private investment is directed to small enclaves while the broader economy remains underdeveloped and subject to high volatility. Finally, the group with zero periods of high volatility has somewhat high foreign aid flows but, thereafter, the ratio of aid flow-to-GDP increases with the number of periods of volatility.

We present a second set of regressions, where observations are organized by the number of periods a country falls into the high volatility regime (Table 7). Column 1 includes only countries with zero periods of high volatility. Here simple OLS suggests that capital inflows are associated with higher growth; moreover, the maximum likelihood estimates (which weight the observations) are virtually identical to the OLS estimates. In this group, there is, thus, no evidence of misspecification. When we add countries with one period of high volatility, the OLS result becomes fuzzy and it takes the maximum likelihood estimates to reveal the positive relationship between capital inflows and growth. The same conclusion applies to the samples that include two and three periods of high volatility.

In summary, we have presented evidence of a break in the reduced form relationship between capital flows and growth when volatility increases beyond a high threshold. Capital inflows are associated with higher growth only in the low volatility regime. This regime also attracts more private capital and, therefore, stimulates productive investment. A high volatility regime, on the other hand, attracts smaller private capital flows and has greater dependence on foreign aid; in this regime, increased capital flows are associated with reduced growth. We pursue the

\footnotetext{
${ }^{10}$ In countries reliant on foreign assistance, continued assistance may reinforce neo-patrimonial tendencies, and retard the development of already weak growth-institutions (Djankov et. al., 2006; Easterly, 2007; Moyo, 2009).
} 
distinctions between private and official flows in the next section, where we also consider the issue of endogeneity of capital flows.

\section{PANEL REgRESSIONS AND ENDOGENEITY}

Our results are subject to the concern that causality may run from growth to capital flows. In cross-sections, this challenge is not easy to confront. Isolating exogenous sources of variation for capital flows has proved particularly difficult. The key difficulty is finding a variable that is correlated with capital flows but does not belong in the growth equation itself. Wei and $\mathrm{Wu}$ (2002) and Portes and Rey (2005) use distances between nations as an instrument for the volume of bilateral capital flows, the idea being that proximity provides informational advantages to investors and is therefore associated with the volume of capital movements. While distance is a plausible instrument for bilateral capital flows, it is less clear how one might instrument for the average size of the current account balance, which measures the overall net inflow or outflow of capital into a country. Alfaro et. al. (2008) propose a measure of “distantness”- a weighted average of the distances from the capital city of one country to the capital cities of other countries. Unfortunately, we found this variable to be weakly correlated with the average size of current account balance and thus not a suitable instrument.

We attempt to address the issue of identification within a panel framework. This also allows us to control for country-specific effects. We estimate our models using the system-GMM estimator outlined in Arellano and Bover (1995) and Blundell and Bond (1998). This estimator is well suited for handling endogenous variables that exhibit a large degree of persistence (Bond et. al., 2001) - a characteristic common to many macro panels. ${ }^{11}$ We report results based on the one-step variant of this estimator, since the standard errors in the two-step estimator are downward biased in finite samples.

Using the threshold level of volatility reported in Table 5, we split the data into high- and lowvolatility samples (Table 8). While we report fixed effects estimates, which are known to be biased, we rely on the Arellano-Bover estimates in drawing inferences. ${ }^{12}$ Fiscal imbalances and institutional quality are omitted from these regressions due to the lack of time-series variation in these data. ${ }^{13}$ Our finding above is confirmed for the low volatility regime. In fact, the relationship in the low volatility setting is stronger within countries than across them. A one percent increase in the current account deficit relative to GDP is associated with a 0.18 percent increase in average annual growth rates, which compares with a 0.09 percent increase in the OLS results. In the high volatility regime, the GMM point estimate on the capital flows coefficient is

\footnotetext{
${ }^{11}$ Bond et. al. (2001) also note that the estimator mitigates the measurement error problem.

${ }^{12}$ Following Arellano and Bond (1991) we are unable to reject the null of the validity of the over-identifying restrictions [Table 7, columns (2) and (4)]. Also second-order serial correlation is absent.

${ }^{13}$ While annual data on fiscal balances are available. For some countries there are large gaps in these data. Calculating five-year averages of this variable would therefore sharply reduce the sample. For this reason we have omitted the fiscal balance variable from our analysis.
} 
indistinguishable from zero- thus, while capital does not foster growth in the high volatility regime, it also does not hurt growth as implied by the OLS (and fixed-effects) estimates. Possibly, negative shocks to growth attract capital inflows to smooth the effects of those shocks. Bluedorn (2005), for instance, finds that a shock valued at one year's GDP pushes the current account into deficit by 5 percent.

\section{A. Breakdown by Type of Flows}

Next, we distinguish between private and official forms of external financing in the low and high volatility regimes (Table 9). We measure flows as the average net inflow of private capital and the average inflow of foreign aid over each of the five-year periods. Because of difficulty in distinction, the estimates of private capital flows from the World Economic Outlook may, in some cases, include a small element of official flows. This limitation is not easy to overcome since better estimates are not available. Alfaro et. al. (2010) consider an alternative measure of private inflows which subtracts official component of capital from the current account balance. Here we do not take this approach, since our estimates of foreign aid, as is conventional, are not just the estimates of official flows on the capital account but also those such as grants, which are included in the current account. Hence the sum of the private capital flows and the official inflows does not equal the current account deficit. In the benchmark specification, we regress growth against flows, initial period income, life expectancy, the average volume of trade flows and time period dummies; a more extended specification also includes population growth, financial development, and financial integration as additional controls.

Inflows of private capital are associated with higher growth in the low volatility regime. In the Arellano-Bover estimates, a one percent increase in private capital inflows relative to GDP could raise growth between 0.14 and 0.24 percent annually (Table 9, columns 2 and 4). Private capital flows and growth are also positively correlated with growth in the high volatility regime (Table 9, columns 5 and 6); however this relationship is not statistically significant or robust (Table 9, column 7).

Foreign aid appears to retard growth during periods of low volatility, but not in a statistically significant manner. The negative coefficients on the aid variable are somewhat larger in the high volatility regime but they are also never significant at the 5 percent level. Moreover, the size of the coefficient is sensitive to the inclusion of Suriname and the Republic of Congo-absent these two countries, the size of the coefficient falls even further. Thus, whether in the low or high volatility regimes, inflows of official flows do not have a significant effect on growth (as Rajan and Subramanian, 2009, conclude). 


\section{Determinants of Volatility}

Our finding that the effect of flows varies across a volatility threshold raises the further question: what exactly does volatility represent? It could be that volatility proxies for a "mysterious" combination of factors that make some economies operate well and others not. So it may not be volatility, per se, that deters foreign investors and creates a poor response to foreign investment. Rather, factors that raise volatility hurt the investment climate.

In considering the determinants of growth volatility, we base our analysis on two recent papers. Malik and Temple (2009) distill, from a Bayesian analysis, the most robust cross-country determinants of volatility. While weak institutions contribute to higher volatility, Malik and Temple (2009) also highlight an important role for the geographical features of an economy, which are associated with production structures that create high volatility conditions. In contrast, Burnside and Tabova (2010) compute a summary metric of volatility generated by time-varying global (external) shocks interacting with an indirect characterization of domestic structural features. We find the Burnside and Tabova (2010) metric to be a surprisingly good proxy for the determinants of country-volatility, both in the cross-section (as they report) and within-countries over time, as in our extension.

To obtain their proxy for exposure to external volatility, for each country, Burnside and Tabova begin by regressing the annual GDP growth rate on six global factors. Three of these-US growth, the three month T-Bill rate corrected for inflation, and excess returns on US stock markets - are related to the phase of the US business cycle, and the other three are shocks to commodity price indexes. We estimate a similar set of equations:

$$
g_{i, j}=\alpha_{i}+x_{j}^{\prime} \beta_{i}+\varepsilon_{i, j}
$$

The dependent variable, $g_{i, j}$, is the annual per-capita GDP growth rate in country $i$ in each year $j=1980, \ldots, 2003$, and $x_{j}$ includes the six global factors in Burnside and Tabova's specification along with the median growth rate in our 61-country sample as a proxy for developing-countrygrowth trends. ${ }^{14}$ The correlation between the median growth rate and errors in the countryspecific growth equation can be assumed to be negligibly small; as such, all explanatory variables can be treated as exogenous.

Growth responds in each country to these exogenous influences in varying ways. That is, for each country, the regressions generate a specific set of $\beta$ 's, which reflect structural features of that country (such as whether it is an oil importer, its relationship to the US, and so on). Although often these growth equations do not have high explanatory power, the volatility of predicted growth rates from the country-specific growth equations is cross-sectionally highly

\footnotetext{
${ }^{14}$ We also considered the mean growth rate in our sample as a regressor, as well as the base Burnside and Tabova specification. These alternatives generated qualitatively robust results.
} 
correlated with actual growth volatilities. This is the basis for Burnside and Tabova's conclusion: conditional on domestic structures, the variation in growth generated by external factors picks up much of the actual variation in cross-country growth rates. In our re-estimation of their results (for a different country set and time period), the coefficient on the volatility of predicted growth rates, $\hat{\sigma}_{i}$, was 1.48 (t-statistic $=7.3$ ) and an R-squared of 0.72 (Table 10 , column 1 ); ${ }^{15}$ this is very similar to the Burnside and Tabova (2010) result, confirming the robustness of their original finding.

In columns 2 and 3 of Table 10, we assess to what extent the Burnside and Tabova (2010) summary measure is capturing standard determinants of volatility, such as those considered by Malik and Temple (2009)—geographical characteristics measuring remoteness to external markets, the volatility of its terms of trade, ethnic fractionalization, the incidence of wars, institutional quality, and government type. Geographical "remoteness” matters for volatility, according to Malik and Temple (2009), since it is associated with undiversified export bases, which makes countries susceptible to volatility.

Our coefficient estimates are generally consistent with Malik and Temple’s results. For instance, output is more volatile in smaller countries and volatility rises (although non-linearly) with a country's distance from the coast. We considered three measures of institutions - the Hall and Jones index, the composite ICRG risk rating and a measure of constraints on the executive branch of government in 1980. All three measures of institutions matter in specifications excluding a proxy for government type. When government type is included in the specification, volatility is found to be lower in democracies (Weede, 1996; Henisz, 2000), and the other institutional variables become insignificant. Thus political institutions dominate other institutional quality ratings. Ethnic fractionalization and external wars combine to raise volatility and in some specifications terms of trade volatility is significant. Together, however, the Malik and Temple (2009) variables account for only 45 percent of the cross-country variation in growth volatility.

In column 3, when we add the Burnside and Tabova measure as an additional regressor in the equation, there is evidence of overlap. The Burnside and Tabova measure has now a smaller point estimate than when entered by itself, but remains highly statistically significant. The Malik and Temple variables retain their signs and significance but are less influential. The interesting conclusion is that the inclusion of the Malik and Temple variables adds little explanatory power, since the Burnside and Tabova variable by itself explains 72 percent of the cross-country variation in growth volatilities, with the R-squared rising to 79 percent following the inclusion of the Malik and Temple variables.

\footnotetext{
${ }^{15}$ Burnside and Tabova (2010) estimate the actual volatility of growth as the standard deviation of the annual real GDP growth rate. To stay consistent with our earlier analysis, we follow Ramey and Ramey (1995) and estimate the volatility of innovations to growth, where we allow the volatility to vary across countries in our sample (see the discussion in section II). Specifically our estimate of growth volatility is obtained from the regression equation reported in Table 1 , column 6 .
} 
For our purpose, it is also important to evaluate the determinants of changes in a country's volatility over time. These changes create the potential for a regime change. It is natural to focus on the Burnside and Tabova measure, which is clearly salient in the cross-section and also has a natural time variation arising from the variation in external factors. The inclusion of countryspecific fixed effects implies, in any case, that the bulk of the Malik and Temple variables drop out. ${ }^{16}$ In column 4 , we report results of within-country estimates of actual volatility regressed on predicted volatilities. After adding time dummies, the variations in actual volatility almost exactly mirror the variations in predicted volatility, implying that the volatility of external influences strongly conditions the changes in a country's volatility.

Finally, there exists the possibility that capital inflows themselves raise volatility. Such a correlation would undermine our finding of a positive relationship between capital flows and growth since the implication would be that beyond a certain size, capital inflows actually hurt growth through their volatility-inducing effects. In columns 5 to 8, we include the average size of current account balances, average net private flows and foreign aid, over five-year windows as regressors in our equation. The results suggest that an inflow of capital, i.e. a current account deficit, is unrelated to output volatility. Private capital flows are negatively associated with volatility and official flows are positively associated; but, given the low statistical significance of these findings, not much can be read from them.

We thus reach a number of conclusions. Externally-induced volatility differentiates country volatility: but, as the Burnside and Tabova method implies, the level of volatility is a function of the domestic structure. The Malik and Temple approach helps identify some of these structural factors: geographical remoteness being particularly important. However, the considerably greater explanatory power of the Burnside and Tabova variable suggests that additional structural features are at play. Our new finding is that changes in volatility over time within a country, conditioned by unchanging structural features, are largely dependent on changes in global drivers. And, finally, capital flows in the aggregate (or private and official flows separately) are not correlated with country growth volatility.

Thus for countries that stay in a particular regime over time, their structural and institutional characteristics matter. Weak institutions raise volatility, but there is much more going on. As a result institutions are not a good proxy for volatility. Geographical remoteness is an important additional feature and other, as yet unidentified, country features also amplify global shocks. In this sense, volatility is an inclusive measure, encompassing several country features that deter international capital and render them less effective. Our results, however, also highlight that the movement of a country in and out of a volatility regime is most likely due to global factors that can be considered largely exogenous to domestic influences.

\footnotetext{
${ }^{16}$ Terms of trade volatility does vary over time but is largely captured by variation in the Burnside and Tabova measure. Institutional variations are captured in the ICRG measure and do show that improved institutions are associated with reduced volatility (results not reported).
} 


\section{CONCLUSION}

The failure to find the expected growth-enhancing role of foreign capital has led some to accept this as a stylized fact. Others have continued an elusive search for non-linearities in that relationship. This paper offers a new perspective. We conclude that non-linearities are important: with countries differentiated by their level of growth volatility. Some countries tend to stay in a volatility regime; but in others, movement from one regime to another causes shifts in the productivity of capital inflows.

We have tried to persuade the reader that our results are not the consequence of a particular sample or methodology. We did so by tracing out the evolution of our result, from a benchmark, where capital flows are negatively correlated with growth - a popular current view-to our final specification where capital flows and growth are positively correlated during periods of low volatility. We find that a standard deviation of innovations to growth of 5.35 percent of real GDP per-capita demarcates low and high volatility regimes. In the high regime, capital inflows are negatively correlated with growth, which also drive the negative correlation between capital inflows and aggregate growth when all countries are pooled. Thus, a failure to distinguish between volatility regimes leads to an unwarranted conclusion that capital inflows are damaging in all situations.

Even when growth and capital flows are positively correlated, the possibility exists that growth causes capital flows. Recognizing the limitations of GMM estimates in dealing with endogeneity, our results suggest that capital inflows do spur growth.

The action in our results comes mainly from private capital flows. In low volatility regimes, countries are able to attract larger private capital flows and gain a growth dividend from these flows; in high volatility settings, private capital flows diminish and have an insignificant relationship with growth. Aid-flows increase in high volatility regimes but whether in a low or high volatility period, aid has a negative relationship with growth.

That a volatility threshold should distinguish the productivity of foreign capital seems natural. Low volatility conditions are more conducive to investment. They thus tend to attract more private capital. ${ }^{17}$ And, in that setting, private capital can undertake more medium-term and riskier investments enhancing growth. In high volatility conditions, reliance on foreign aid is greater, which has had a poor record of accelerating growth.

\footnotetext{
${ }^{17}$ Some heavily commodity-reliant economies do attract private capital that is large in relation to the economy but being of an enclave nature has limited impact on growth or in mitigating the volatility of that economy.
} 
Our exploration of the determinants of volatility showed that structural features, that include geographical remoteness, distinguish levels of a country's growth volatility. Weak institutions do raise volatility, but are only part of the explanation and hence do not, by themselves distinguish capital flow-growth regimes. Our findings also imply that the shift from one regime to another is largely a function of changes in global factors.

A final implication of our findings is that statements about "long-run" effects of foreign capital do not apply when countries move in and out of regimes. As noted, only 26 of the 61 countries in our sample were in the low volatility regime throughout the period analyzed. For the other 35 countries, the effective long-run relationship between capital inflows and growth will be a combination of the effects in low and high volatility regimes. 


\section{References}

Acemoglu, D., Johnson, S., Robinson, J., Thaicharoen, Y., 2003, “Institutional Causes, Macroeconomic Symptoms: Volatility, Crises and Growth,” Journal of Monetary Economics, 50(1): 49-123.

Alesina, A., Devleeschauwer, A., Easterly, W., Kurlat, S., Wacziarg, R., 2003, "Fractionalization,” Journal of Economic Growth, 8(2): 155-194.

Alfaro, L., Kalemli-Ozcan, S., Volosovych, V., 2008, "International Capital Allocation, Sovereign Borrowing, and Growth,” Harvard Business School Working Paper. , 2008, “Why Doesn't Capital Flow from Rich to Poor Countries? An Empirical Investigation,” The Review of Economics and Statistics, 90(2): 347-68.

Arellano, M., Bond, S., 1991, “Some Tests of Specification for Panel Data: Monte Carlo Evidence and an Application to Employment Equations,” Review of Economic Studies, 58(2): 277-97.

Arellano, M., Bover, O., 1995, “Another Look at the Instrumental Variable Estimation of ErrorComponents Models,” Journal of Econometrics, 68(1): 29-51.

Arteta, C., Eichengreen, B., Wyplosz, C., 2003, “When Does Capital Account Liberalization Help More than it Hurts?” In Elhanan Helpman and Efraim Sadka (eds.), Economic Policy in the International Economy, Cambridge: Cambridge University Press, pp.177206.

Bachmann, R., Elstner, S., Sims, E., 2010, “Uncertainty and Economic Activity: Evidence from Business Survey Data,” NBER Working Paper No. 16143.

Bluedorn, J., 2005, “Hurricanes: Intertemporal Trade and Capital Shocks,” Economics Series Working Papers 241, University of Oxford, Department of Economics.

Blundell, R., Bond, S., 1998, “Initial Conditions and Moment Restrictions in Dynamic Panel Data Models,” Journal of Econometrics, 87(1): 115-143.

Bond, S., Hoeffler, A., Temple, J., 2001, “GMM Estimation of Empirical Growth Models,” CEPR Discussion Paper No. 3048.

Burnside, C., Tabova, A., 2010, “Risk, Volatility, and the Global Cross-Section of Growth Rates,” National Bureau of Economic Research Working Paper No. 15225.

Deaton, A., 2010, “Instruments, Randomization, and Learning about Development,” Journal of Economic Literature, 48(2): 424-55. 
Devereux, M., Sutherland, A., 2009, "A Portfolio Model of Capital Flows to Emerging Markets," Journal of Development Economics, 89(2): 181-93.

Djankov, S., Montalvo, J., Reynal-Querol, M., 2008, “The Curse of Aid,” Journal of Economic Growth, 13(3): 169-94.

Easterly, W., 2007, Was Development Assistance a Mistake? American Economic Review, 97(2): 328-32.

Eichengreen, B., 2007, “The Cautious Case for Capital Flows,” CID Working Papers 1, Harvard University.

Gallup, J., Sachs, J., Mellinger, A., 1999, “Geography and Economic Development,” Harvard University CID Working Papers 1.

Gourinchas, P-O., Jeanne, O., 2007, “Capital Flows to Developing Countries: The Allocation Puzzle,” NBER Working Paper No. 13602.

Hall, R., and Jones, C., 1999, "Why Do Some Countries Produce so much more Output per Worker than Others?” Quarterly Journal of Economics, 114: 83-116.

Hansen, B., 2000, “Sample Splitting and Threshold Estimation,” Econometrica, 68(3): 575-603. , 1999, "Threshold Effects in Non-Dynamic Panels, Estimation, Testing, and Inference,” Journal of Econometrics, 93(2): 345-68. , 1996, "Inference When a Nuisance Parameter is not Identified Under the Null Hypothesis," Econometrica, 64(2): 413-30.

Henisz, W., 2000, “The Institutional Environment for Economic Growth,” Economics and Politics 12(1): 1-31.

Jerzmanowski, M., 2006, "Empirics of Hills, Plateaus, Mountains and Plains: A MarkovSwitching Approach to Growth,” Journal of Development Economics, 81(2): 357-85.

Kose, A., Prasad, E., Taylor, A., 2009, "Thresholds in the Process of International Financial Integration,” NBER Working Paper No. 14916.

Kose, A., Prasad, E., Rogoff, K., Wei, S-J., 2006, “Financial Globalization: A Reappraisal,” International Monetary Fund Working Paper No. 06/189.

Krebs, T., Krishna, P., Maloney, W., 2010, Trade Policy, Income Risk, and Welfare,” Review of Economic Statistics, 92(3): 467-81. 
Lane, P., Milesi-Ferretti, G-M., 2007, “The External Wealth of Nations Mark II: Revised and Extended Estimates of Foreign Assets and Liabilities, 1970-2004,” Journal of International Economics, 73(2): 223-250.

Malik, A., Temple, J., 2009, “The Geography of Output Volatility,” Journal of Development Economics, 90(2): 163-178.

Moyo, D., 2009, Dead Aid: Why Aid Is Not Working and How There Is Another Way for Africa. London: Allen Lane.

Portes, R., Rey, H., 2005, “The Determinants of Cross-Border Equity Transaction Flows,” Journal of International Economics, 65(2): 269-296.

Prasad, E., Rajan, R., Subramanian, A., 2007, “The Paradox of Capital,” Finance and Development, 44(1).

, 2006, "Patterns of International Capital Flows and their Implications for Economic Development,” presented at the symposium, “The New Economic Geography: Effects and Policy Implications,” The Federal Reserve Bank of Kansas City, Jackson Hole, Wyoming, August 24-26.

Pritchett, L., 2000, “Understanding Patterns of Economic Growth: Searching for Hills Among Plateaus, Mountains, and Plains,” World Bank Economic Review, 14 (2): 221-50.

Ramey, G., Ramey, V., 1995, “Cross-Country Evidence on the Link between Volatility and Growth,” American Economic Review, 85(5): 1138-51.

Rajan, R., Subramanian, A., 2009, “Aid, Dutch Disease, and Manufacturing Growth,” Center for Global Development Working Paper No. 196.

Rogers, W., 1993, “Regression Standard Errors in Clustered Samples,” Stata Technical Bulletin, 3(13): 19-23.

Sandri, D., 2010, “Growth and Capital Flows With Risky Entrepreneurship,” IMF Working Paper 10/37.

Sirimaneetham, V., Temple, J., 2009, “Macroeconomic Stability and the Distribution of Growth Rates,” World Bank Economic Review, 23(3):443-79.

Weede, E., 1996, "Political Regime Type and Variation in Economic Growth Rates,” Constitutional Political Economy, 7(3): 167-176.

Wei, S-J., Wu, Y., 2002, "Negative Alchemy? Corruption, Composition of Capital Flows, and Currency Crises,” in Sebastian Edwards and Jeffrey A. Frankel (eds), Preventing 
Currency Crises in Emerging Markets, Chicago: The University of Chicago Press, pp. 461-506.

Zarnowitz, V., Moore, G., 1986, "Major Changes in Cyclical Behavior,” in Robert J. Gordon (ed), The American Business Cycle: Continuity and Change. Chicago: University of Chicago Press, pp. 519-72. 


\section{Appendix I. Variables and Data Sources}

Table A.1. Descriptions of Variables and Data Sources

\begin{tabular}{|c|c|}
\hline Variable & $\begin{array}{l}\text { Description } \\
\text { Dependent Variable }\end{array}$ \\
\hline \multirow[t]{2}{*}{ Growth } & $\begin{array}{l}\text { Calculated as the log difference of chained real GDP }(\times 100) \text { (series } \\
\text { rgdpch, Penn World Tables } 6.2) \text {. In a number of regressions the dependent } \\
\text { variable is the annual growth rate. In others, it is the average, either over } \\
\text { the entire sample period } 1980 \text { to } 2003 \text {, or over the following non- } \\
\text { overlapping periods: } 1980-84,1985-89,1990-94,1995-99 \text {, and } 2000-03 \text {. }\end{array}$ \\
\hline & Explanatory Variables \\
\hline Current Account & $\begin{array}{l}\text { Expressed as a percent of GDP (series BCA, World Economic Outlook). In } \\
\text { our regressions the current account appears as an average per country, } \\
\text { either over the entire sample period or from 1980-84, 1985-89, 1990-94, } \\
1995-99 \text {, and } 2000-03 \text {. }\end{array}$ \\
\hline $\begin{array}{l}\text { Ethnic } \\
\text { Fractionalization }\end{array}$ & $\begin{array}{l}\text { Computed as one minus the Herfindahl index of ethnolinguistic group } \\
\text { share, reflecting the probability that two randomly selected individuals from } \\
\text { a population belonged to different groups (Alesina, Devleeschauwer, } \\
\text { Easterly, Kurlat and Wacziarg, 2003). }\end{array}$ \\
\hline $\begin{array}{l}\text { Financial } \\
\text { Development }\end{array}$ & $\begin{array}{l}\text { Private credit as a percent of GDP intermediated through the financial } \\
\text { sector (World Bank, Financial Structure Database). }\end{array}$ \\
\hline $\begin{array}{l}\text { Financial } \\
\text { Integration }\end{array}$ & $\begin{array}{l}\text { Sum of stocks of (the absolute value of) external assets plus external } \\
\text { liabilities as a percentage of GDP (Lane and Milesi-Ferretti, 2007). }\end{array}$ \\
\hline Fiscal Balance & $\begin{array}{l}\text { General government balance expressed as a percent of GDP (series GGB, } \\
\text { World Economic Outlook). Due to the paucity of these data, this variable } \\
\text { appears only in our cross-country regressions as an average for the entire } \\
\text { sample period. }\end{array}$ \\
\hline Foreign Aid & $\begin{array}{l}\text { Net official development assistance, (series DT.ODA.ALLD.CD, World } \\
\text { Development Indicators, 2008). In our regressions, we take the average of } \\
\text { this variable, either over the entire sample period, or over the following } \\
\text { periods: } 1980-84,1985-89,1990-94,1995-99 \text {, and } 2000-03 \text {. }\end{array}$ \\
\hline Government Type & $\begin{array}{l}\text { Calculated as the difference between democracy and autocracy scores } \\
\text { (Polity IV project). }\end{array}$ \\
\hline Institutional Quality & $\begin{array}{l}\text { A measure of government anti-diversion policies (Hall and Jones, 1999), } \\
\text { which, following Knack and Keefer (1995), is constructed as an average of } \\
\text { five ICRG variables that reflect the security of private property and the } \\
\text { enforceability of contracts: "Corruption in Government," the "Rule of Law," } \\
\text { "Expropriation Risk," "Repudiation of Contracts by Government," and } \\
\text { "Quality of the Bureaucracy." This variable is measured for each country } \\
\text { around 1985. }\end{array}$ \\
\hline
\end{tabular}


Initial Income

Life Expectancy

Land Area from

Coast

Landlocked

Openness

Population

Population Growth

Private Capital

Primary

Commodities Price

Indexes

\section{US Real GDP \\ Growth}

US Real Interest

Rates

US Excess Returns
Log of real per capita GDP adjusted for differences in purchasing power (series rgdpl, Penn World Tables 6.2). In our regressions this variable is either the 1980 value, or the initial value in each of the following periods: 1980-84, 1985-89, 1990-94, 1995-99, and 2000-03.

Measured in years (series SP.DYN.LE00.IN, World Development Indicators, 2008). In our regressions it is either the 1980 value, or the initial period value in each of our five non-overlapping periods.

The proportion of a country's total area within $100 \mathrm{~km}$ of the ocean or ocean navigable river (Gallup, Sachs and Mellinger, 1999).

Dummy for landlocked country (Gallup, Sachs and Mellinger, 1999).

Total volume of trade flows expressed as a percent of GDP (series NE.TRD.GNFS.ZS, World Development Indicators, 2008). In our regressions, we take the average of this variable, either over the entire sample period, or over following periods: 1980-84, 1985-89, 1990-94, 1995-99, and 2000-03.

The logarithm of the initial population in 1980 (series SP.POP, World Development Indicators, 2008).

Population growth (series SP.POP.GROW, World Development Indicators, 2008). In our regressions, we take the average of this variable over the following periods: 1980-84, 1985-89, 1990-94, 1995-99, and 2000-03..

The sum of net direct investment, net portfolio flows, and other net private capital flows (series BFXP, World Economic Outlook). Because of data limitations "other private capital flows, net" are calculated by subtracting liabilities to official creditors from total other investment. As such, these data may include some official investment. In our regressions, we take the average of this variable over the following periods: 1980-84, 1985-89, 1990-94, 1995-99, and 2000-03.

Oil, metals, and agricultural products price indices, converted to relative prices using the US PPI (Burnside and Tabova, 2010).

Calculated as the log difference of US real GDP per capita in constant 2000 dollars ( $\times 100)$ (Burnside and Tabova, 2010).

Difference between the 3 month T-bill rate and the rate of inflation of the US producer price index (Burnside and Tabova, 2010).

Excess return on the US stock market (Burnside and Tabova, 2010, original source:

http://mba.tuck.dartmouth.edu/pages/faculty/ken.french/data library.html). 
Volatility of Terms of Trade

War
The standard deviation from 1980 to 2003 of the log difference in net terms of trade $(\times 100)$ (series TT.PRI.MRCH.XD.WD, World Development Indicators, some gaps filled using data from International Financial Statistics).

Dummy for whether a country had an external war between 1960 and 1985 (Gallup, Sachs and Mellinger, 1999). 
Table A.2. List of Countries: Main Sample

\begin{tabular}{|c|c|}
\hline \multicolumn{2}{|c|}{$\begin{array}{c}61 \text { Country Sample } \\
\end{array}$} \\
\hline East Asia and the Pacific & Middle East and North Africa \\
\hline China & Algeria \\
\hline Fiji & Egypt \\
\hline Hong Kong & Iran \\
\hline Indonesia & Israel \\
\hline Korea & Malta \\
\hline Malaysia & Morocco \\
\hline Philippines & Oman \\
\hline Thailand & Saudi Arabia \\
\hline East and Central Europe & Syria \\
\hline Hungary & Tunisia \\
\hline Poland & South Asia \\
\hline Romania & India \\
\hline Turkey & Pakistan \\
\hline Latin America and the Caribbean & Sri Lanka \\
\hline Argentina & Sub-Saharan Africa \\
\hline Bahamas & Botswana \\
\hline Barbados & Cameroon \\
\hline Bolivia & Republic of Congo \\
\hline Brazil & Cote d’Ivoire \\
\hline Chile & Ethiopia \\
\hline Colombia & Ghana \\
\hline Costa Rica & Kenya \\
\hline Dominican Republic & Mauritius \\
\hline El Salvador & Namibia \\
\hline Guatemala & Nigeria \\
\hline Haiti & South Africa \\
\hline Honduras & Swaziland \\
\hline Jamaica & Zimbabwe \\
\hline Mexico & Western Europe \\
\hline Panama & Cyprus \\
\hline Paraguay & \\
\hline Peru & \\
\hline Suriname & \\
\hline Trinidad \&Tobago & \\
\hline Uruguay & \\
\hline Venezuela & \\
\hline
\end{tabular}


Table 1. Cross-Country Current Account-Growth Relationship in Developing Countries

\begin{tabular}{|c|c|c|c|c|c|c|}
\hline \multicolumn{7}{|c|}{ Dependent Variable: Average of Annual Growth Rates 1970/1980 to 2000/2003; Annual Growth Rates 1980 to 2003} \\
\hline & \multicolumn{4}{|c|}{ OLS } & \multicolumn{2}{|c|}{ MaximumLikelihood } \\
\hline & $\begin{array}{r}\text { Prasad et al. } \\
(2006)\end{array}$ & $\begin{array}{r}\text { Replicating } \\
\text { Prasad et. al. } \\
(2006)\end{array}$ & $\begin{array}{r}\text { Dropping Aid } \\
\text { Dependent } \\
\text { Countries }\end{array}$ & $\begin{array}{r}\text { Dependent } \\
\text { Variable is } \\
\text { Annual Growth } \\
\text { Rate }\end{array}$ & $\begin{array}{r}\text { Ramey and } \\
\text { Ramey (1995) }\end{array}$ & $\begin{array}{r}\text { Ramey and } \\
\text { Ramey (1995) } \\
\text { excluding volatility }\end{array}$ \\
\hline & $(1-1)$ & $(1-2)$ & $(1-3)$ & $(1-4)$ & $(1-5)$ & $(1-6)$ \\
\hline \multirow[t]{2}{*}{ Current Account Balance } & 0.098 & 0.060 & 0.012 & 0.012 & -0.013 & -0.027 \\
\hline & (2.13) & (1.45) & (0.13) & $(0.15)$ & $-(0.14)$ & $-(0.27)$ \\
\hline \multirow[t]{2}{*}{ Initial Income } & -1.257 & -1.584 & -1.782 & -1.782 & -2.248 & -2.168 \\
\hline & $-(6.19)$ & $-(4.22)$ & $-(3.72)$ & $-(4.77)$ & $-(4.79)$ & $-(4.07)$ \\
\hline \multirow[t]{2}{*}{ Initial Life Expectancy } & 0.032 & 0.138 & 0.111 & 0.111 & 0.091 & 0.082 \\
\hline & (1.33) & (3.56) & (2.32) & (2.91) & (2.16) & (2.24) \\
\hline \multirow[t]{2}{*}{ Openness } & 1.879 & 0.005 & 0.008 & 0.008 & 0.013 & 0.013 \\
\hline & (2.90) & (1.30) & (1.84) & (2.23) & (4.54) & (5.90) \\
\hline \multirow[t]{2}{*}{ Institutional Quality } & 4.252 & 5.084 & 6.745 & 6.745 & 7.644 & 7.666 \\
\hline & $(2.77)$ & (2.99) & (3.58) & $(4.07)$ & (4.68) & (4.36) \\
\hline \multirow[t]{2}{*}{ Fiscal Balance } & 0.023 & 0.066 & 0.043 & 0.043 & -0.012 & -0.043 \\
\hline & $(0.52)$ & $(0.89)$ & $(0.56)$ & $(0.65)$ & $-(0.17)$ & $-(0.65)$ \\
\hline \multirow[t]{2}{*}{ Volatility } & & & & & $-(0.24)$ & \\
\hline & & & & & $-(1.85)$ & \\
\hline Number of Countries & 60 & 87 & 61 & 61 & 61 & 61 \\
\hline Number of Observations & 60 & 87 & 61 & 1464 & 1464 & 1464 \\
\hline
\end{tabular}

Notes: In column 1, which reproduces the results reported in Prasad et. al. (2006), the dependent variable is the average real per capita GDP growth rate from 1970 to 2000 . The current account and fiscal balance, are averages over the same period. Life expectancy, income and openness - the Sachs and Warner dummy-are measured in 1970 (or the earliest available date), and institutional quality, which is taken from Hall and Jones (1999), is measured around 1985. In regressions 2 to 6, the sample period is from 1980 to 2003 and openness is measured using the average trade volumes (relative to GDP) over this sample period. In columns 2 to 3 the dependent variable continues to be the average growth rate of real GDP per-capita. The regressions in columns 4 to 6 are based on a pooled panel of observations. The dependent variable in these cases is the annual growth rate for each country in our sample however the covariates continue be sample-period averages and initial periodvalues of our controls. The numbers in parentheses below the coefficients are t-statistics. In columns 1 to 3 these t-statistics are based on robust standard errors. In columns 4 to 6 , we make allowance for within country cluster dependence, by adjusting the standard errors using the Rogers (1993) approach. In columns 5 to 6 , estimation is by maximum likelihood. 
Table 2. Current Account-Growth Relationship in Developing Countries: Weighted Regressions

\begin{tabular}{|c|c|c|c|c|}
\hline & $\begin{array}{r}19 \\
19\end{array}$ & $\begin{array}{l}\text { Rates } 1970 / 1980 \\
0 \text { to } 2003\end{array}$ & 03; Ani & Rates \\
\hline & \multicolumn{4}{|c|}{ Maximum Likelihood } \\
\hline & \multirow[t]{2}{*}{$\begin{array}{r}\text { Explanatory } \\
\text { Variables: 24- } \\
\text { Year Averages } \\
\text { and Intial Values } \\
(2-1)\end{array}$} & \multicolumn{3}{|c|}{$\begin{array}{l}\text { Explanatory Variables: Five-Year Averages and Initial } \\
\text { Values, Except Institutional Quality and Fiscal Balance }\end{array}$} \\
\hline & & $(2-2)$ & $(2-3)$ & $(2-4)$ \\
\hline \multirow[t]{2}{*}{ Current Account Balance } & -0.082 & -0.068 & -0.070 & -0.091 \\
\hline & $-(1.66)$ & $-(1.99)$ & $-(2.01)$ & $-(3.38)$ \\
\hline \multirow[t]{2}{*}{ Initial Income } & -1.763 & -2.186 & -1.986 & -2.247 \\
\hline & $-(3.22)$ & $-(3.45)$ & $-(2.70)$ & $-(2.88)$ \\
\hline \multirow[t]{2}{*}{ Initial Life Expectancy } & 0.068 & 0.127 & 0.115 & 0.126 \\
\hline & $(1.83)$ & (3.37) & $(2.30)$ & (2.45) \\
\hline \multirow[t]{2}{*}{ Openness } & 0.013 & 0.014 & 0.015 & 0.153 \\
\hline & $(5.47)$ & $(5.39)$ & $(4.89)$ & (5.42) \\
\hline \multirow[t]{2}{*}{ Institutional Quality } & 7.882 & 9.613 & 9.741 & 10.510 \\
\hline & $(4.83)$ & $(5.08)$ & $(4.88)$ & $(5.48)$ \\
\hline \multirow[t]{2}{*}{ Fiscal Balance } & -0.062 & & -0.069 & -0.730 \\
\hline & $-(1.14)$ & & $-(1.34)$ & $-(1.46)$ \\
\hline Number of Countries & 61 & 61 & 61 & 61 \\
\hline Number of Observations & 1464 & 1429 & 1429 & 1429 \\
\hline
\end{tabular}

Notes: The regressions are based on a pooled panel of observations. The dependent variable in each case is the annual growth rate of real GDP per capita from 1980 to 2003 for each country in our sample however the covariates are sample-period averages and initial period-values of our controls. In regression (1), averages are taken over the entire sample period, and initial values are measured in 1980. In the remainder of the regressions averages are taken over five- (and four-year) periods, while income and life expectancy are initial period values. In regression (2-4) we include time period dummies, although the coefficients are not reported here. The models are estimated using maximum likelihood, where the specification assumes that the volatility can vary across countries as well as within countries over fiveyear (and four-year) intervals. The numbers in parentheses below the coefficients are t-statistics corrected for cluster dependence. 
Table 3. Within and Between Country Variation in Volatility

\begin{tabular}{|l|r|r|r|}
\hline & Overall & Between & Within \\
\hline Mean & 4.43 & & \\
\hline Standard Deviation & 3.26 & 2.38 & 2.23 \\
\hline Minimum & 0.27 & 1.24 & -4.23 \\
\hline Maximum & 25.65 & 13.99 & 17.17 \\
\hline
\end{tabular}

Notes: The negative value for the minimum within volatility is not an error; the "within" column is showing the variation of volatility within countries around the global mean. 
Table 4. Current Account, Growth and Volatility: Interactions

\begin{tabular}{|c|c|c|c|c|}
\hline \multicolumn{5}{|c|}{ Dependent Variable: Average Growth Rate, 1980 to $1984 ; 1985$ to $1989 ; 1990$ to $1994 ; 1995$ to $2000 ; 2000$ to 2003} \\
\hline & $(4-1)$ & $(4-2)$ & $(4-3)$ & $(4-4)$ \\
\hline \multirow[t]{2}{*}{ Current Account Balance } & -0.042 & 0.058 & 0.089 & 0.159 \\
\hline & $-(0.82)$ & $(0.86)$ & $(1.07)$ & (1.75) \\
\hline \multirow[t]{2}{*}{ Volatility ${ }^{*}$ Current Account Balance } & 0.010 & & & \\
\hline & (1.18) & & & \\
\hline \multirow[t]{2}{*}{ Low Volatility ${ }^{*}$ Current Account Balance } & & -0.112 & & \\
\hline & & $-(1.71)$ & & \\
\hline \multirow[t]{2}{*}{ Medium Low Volatility ${ }^{\star}$ Current Account Balance } & & & -0.151 & \\
\hline & & & $-(1.77)$ & \\
\hline \multirow[t]{2}{*}{ Medium High Volatility*Current Account Balance } & & & & -0.234 \\
\hline & & & & $-(2.54)$ \\
\hline \multirow[t]{2}{*}{ Initial Income } & -2.145 & -2.183 & -2.197 & -2.259 \\
\hline & $-(4.08)$ & $-(4.25)$ & $-(4.40)$ & $-(4.22)$ \\
\hline \multirow[t]{2}{*}{ Initial Life Expectancy } & 0.130 & 0.138 & 0.128 & 0.126 \\
\hline & $(2.83)$ & $(3.14)$ & $(3.04)$ & (3.03) \\
\hline \multirow[t]{2}{*}{ Openness } & 0.012 & 0.011 & 0.011 & 0.013 \\
\hline & (3.34) & (2.91) & $(3.17)$ & (3.86) \\
\hline \multirow[t]{2}{*}{ Institutional Quality } & 8.570 & 8.859 & 8.732 & 8.604 \\
\hline & $(4.23)$ & $(4.44)$ & $(4.15)$ & $(4.10)$ \\
\hline \multirow[t]{2}{*}{ Fiscal Balance } & 0.068 & 0.074 & 0.102 & 0.097 \\
\hline & $(0.88)$ & $(0.99)$ & $(1.35)$ & (1.16) \\
\hline \multirow[t]{2}{*}{ Volatility } & -0.076 & & & \\
\hline & $-(0.64)$ & & & \\
\hline \multirow[t]{2}{*}{ Low Volatility $(<2.54 \%)$} & & 0.600 & & \\
\hline & & (1.95) & & \\
\hline \multirow[t]{2}{*}{ Medium Low Volatility $(<3.86 \%)$} & & & 0.896 & \\
\hline & & & $(2.22)$ & \\
\hline \multirow[t]{2}{*}{ Medium High Volatility $(<5.35 \%)$} & & & & 1.064 \\
\hline & & & & $(2.42)$ \\
\hline \multirow[t]{2}{*}{ Impact of current account in low/mid-low/mid-high regime } & & -0.053 & -0.062 & -0.075 \\
\hline & & $-(1.66)$ & $-(1.83)$ & $-(1.89)$ \\
\hline Number of Countries & 61 & 61 & 61 & 61 \\
\hline Number of Observations & 298 & 298 & 298 & 298 \\
\hline
\end{tabular}

Notes: In each case, the dependent variable is the average real GDP per capita growth rate over the following non-overlapping intervals: 1980-84, 1985-89, 1990-94, 1995-99, and 2000-03. Income and life expectancy are initial period values and openness is the period average. Fiscal balance however continues to be measured using an average for the entire sample period and institutional quality is measured around 1985 . Our estimate of volatility was obtained from the regression reported in Table 2, column 4, where it was estimated jointly with the growth equation as a model parameter. Dummies for low, medium-low and medium-high volatility indicate whether volatility lies in the lowest 25th percentile, in the lowest 50th percentile or the lowest 75th percentile. In each specification, we include time period dummies, though the coefficients on these variables not reported. The numbers in parentheses below the coefficients are t-statistics corrected for cluster dependence. At the bottom of the table, in addition to the number of countries and sample size, we report the magnitude of the relationship between the current account and growth in each of the volatility regimes, along with the corresponding t-statistic. 
Table 5. Threshold Effects

\begin{tabular}{|c|c|c|c|c|c|c|}
\hline \multicolumn{7}{|c|}{ Dependent Variable: Average Growth Rate, 1980 to 1984; 1985 to 1989; 1990 to 1994; 1995 to 2000; 2000 to 2003} \\
\hline & & & Low Regime & High Regime & Low Regime & High Regime \\
\hline & Low Regime $\sigma \leq$ & High Regime $\sigma>$ & institutions $\leq$ & instititutions > & income $\leq$ & income > \\
\hline & 5.35 & 5.35 & 0.614 & 0.614 & 7.76 & 7.76 \\
\hline & $(5-1)$ & $(5-2)$ & $(5-3)$ & $(5-4)$ & $(5-5)$ & $(5-6)$ \\
\hline \multirow[t]{2}{*}{ Current Account Balance } & -0.094 & 0.177 & -0.029 & 0.115 & 0.189 & -0.034 \\
\hline & $-(2.86)$ & $(2.07)$ & $-(0.44)$ & $(1.80)$ & $(2.13)$ & $-(0.75)$ \\
\hline \multirow[t]{2}{*}{ Initial Income } & -2.299 & -2.299 & -2.175 & -2.175 & -2.211 & -2.211 \\
\hline & $-(6.10)$ & $-(6.10)$ & $-(5.86)$ & $-(5.86)$ & $-(5.80)$ & $-(5.80)$ \\
\hline \multirow[t]{2}{*}{ Initial Life Expectancy } & 0.136 & 0.136 & 0.136 & 0.136 & 0.114 & 0.114 \\
\hline & (3.85) & (3.85) & (3.79) & (3.79) & (3.21) & (3.21) \\
\hline \multirow[t]{2}{*}{ Openness } & 0.013 & 0.013 & 0.011 & 0.011 & 0.012 & 0.012 \\
\hline & (3.76) & (3.76) & (3.03) & (3.03) & (3.66) & (3.66) \\
\hline \multirow[t]{2}{*}{ Institutional Quality } & 8.916 & 8.916 & 9.378 & 9.378 & 9.086 & 9.086 \\
\hline & $(5.97)$ & $(5.97)$ & (5.78) & $(5.78)$ & $(6.30)$ & (6.30) \\
\hline \multirow[t]{2}{*}{ Fiscal Balance } & 0.095 & 0.095 & 0.065 & 0.065 & 0.071 & 0.071 \\
\hline & $(1.61)$ & $(1.61)$ & $(1.08)$ & $(1.08)$ & $(1.22)$ & (1.22) \\
\hline \multirow[t]{2}{*}{ Volatility } & -0.052 & -0.052 & -0.135 & -0.135 & -0.099 & -0.099 \\
\hline & $-(0.43)$ & $-(0.43)$ & $-(1.18)$ & $-(1.18)$ & $-(0.87)$ & $-(0.87)$ \\
\hline Threshold & \multicolumn{2}{|c|}{5.35} & \multicolumn{2}{|c|}{0.61} & \multicolumn{2}{|c|}{7.76} \\
\hline 95\% confidence interval & \multicolumn{2}{|c|}{$(3.21,6.96)$} & \multicolumn{2}{|c|}{$(0.24,0.79)$} & \multicolumn{2}{|c|}{$(6.13,10.34)$} \\
\hline$p$-value & \multicolumn{2}{|c|}{$(0.02)$} & \multicolumn{2}{|c|}{$(0.54)$} & \multicolumn{2}{|c|}{$(0.20)$} \\
\hline Number of observations & 225 & 73 & 202 & 96 & 55 & 243 \\
\hline Number of countries & 59 & 35 & 41 & 20 & 15 & 55 \\
\hline Joint R-square & \multicolumn{2}{|c|}{0.26} & \multicolumn{2}{|c|}{0.23} & \multicolumn{2}{|c|}{0.24} \\
\hline
\end{tabular}

Notes: The dependent variable is the average growth rate over the following non-overlapping intervals: 1980-84, 1985-89, 1990-94, 1995-99, and 2000-03. Income and life expectancy are initial period values and openness is the period average. Fiscal balance however continues to be measured using an average for the entire sample period and institutional quality is measured around 1985. Our estimate of volatility was obtained from the regression reported in Table 2, column 4, where it was estimated jointly with the growth equation as a model parameter. All the specifications include time-period dummies (coefficients not reported). Threshold regressions were performed using a Gauss code adapted from Hansen (2000). In columns 1 and 2 the threshold variable is the volatility of growth, in columns 3 and 4 the threshold variable is the Hall and Jones (1999) institutions measure, in columns 5 and 6 the threshold variable is income. At the bottom of the table, we report in parentheses the p-values associated with Hansen's test of threshold significance, which were generated by bootstrap using 1,000 replications. Also reported are the number of observations and countries that constitute each regime. 
Table 6. Descriptive Statistics by Regime

\begin{tabular}{|c|c|c|c|c|c|c|c|c|c|c|c|}
\hline \multicolumn{12}{|c|}{ Panel A } \\
\hline & & Grouth & $\begin{array}{r}\text { Ourrent } \\
\text { Account }\end{array}$ & $\begin{array}{r}\text { Private } \\
\text { Fows }\end{array}$ & $\begin{array}{l}\text { Official } \\
\text { Hows }\end{array}$ & Income & $\begin{array}{r}\text { Life } \\
\text { Expectancy }\end{array}$ & $\begin{array}{r}\text { Trade } \\
\text { Volume }\end{array}$ & Institutions & $\begin{array}{r}\text { Fiscal } \\
\text { Balance }\end{array}$ & Volatility \\
\hline \multicolumn{2}{|c|}{ Low Volatility Regime } & 1.88 & -1.85 & 1.64 & 2.14 & 8.54 & 66.35 & 71.75 & 0.58 & -3.26 & 3.07 \\
\hline & & (2.23) & $(4.04)$ & $(4.06)$ & $(2.83)$ & (0.76) & (7.34) & (45.79) & (0.12) & (3.75) & $(1.36)$ \\
\hline \multicolumn{2}{|c|}{ High Volatility Regime } & -0.10 & -2.06 & 0.92 & 3.64 & 8.27 & 62.05 & 68.28 & 0.53 & -4.90 & 8.61 \\
\hline & & $(4.64)$ & $(6.38)$ & (4.61) & $(3.98)$ & $(0.86)$ & $(8.49)$ & $(39.97)$ & $(0.12)$ & $(4.64)$ & $(3.82)$ \\
\hline \multicolumn{12}{|c|}{ Panel B } \\
\hline & Countries with & Grouth & $\begin{array}{r}\text { Ourrent } \\
\text { Account }\end{array}$ & $\begin{array}{r}\text { Private } \\
\text { Fows }\end{array}$ & $\begin{array}{l}\text { Official } \\
\text { Fons }\end{array}$ & Income & $\begin{array}{r}\text { Life } \\
\text { Expectancy }\end{array}$ & $\begin{array}{r}\text { Trade } \\
\text { Volume }\end{array}$ & Institutions & $\begin{array}{r}\text { Fiscal } \\
\text { Balance }\end{array}$ & Volatility \\
\hline Full Sample & \multirow{3}{*}{$\begin{array}{r}\text { zero periods of } \\
\text { high volatility }\end{array}$} & 175 & -222 & 192 & 221 & 8.64 & $\quad 66.54$ & 7232 & 0.57 & -3.91 & 268 \\
\hline Low Volatility Regime & & 1.75 & -2.22 & 1.92 & 2.21 & 8.64 & 66.54 & 72.32 & 0.57 & -3.91 & 268 \\
\hline High Volatility Regime & & NA & NA & NA & NA & NA & NA & NA & NA & NA & NA \\
\hline Full Sample & \multirow{3}{*}{$\begin{array}{r}\text { one period of high } \\
\text { volatility }\end{array}$} & 273 & -1.44 & 124 & 134 & 8.54 & 69.46 & 84.50 & 0.61 & -1.58 & 3.48 \\
\hline Low Volatility Regime & & 2.73 & -1.44 & 1.56 & 2.14 & 8.54 & 69.46 & 84.50 & 0.61 & -1.58 & 3.43 \\
\hline High Volatility Regime & & 0.53 & -2.01 & -0.04 & 2.19 & 8.61 & 69.07 & 87.95 & 0.61 & -3.12 & 7.26 \\
\hline Full Sample & \multirow{3}{*}{$\begin{array}{r}\text { two periods of high } \\
\text { volatility }\end{array}$} & -0.37 & -1.36 & 115 & 174 & 8.44 & 6169 & 67.23 & 0.55 & -270 & 5.34 \\
\hline Low Volatility Regime & & 0.98 & -2.18 & 1.76 & 1.69 & 8.41 & 61.74 & 61.98 & 0.56 & -2.36 & 3.82 \\
\hline High Volatility Regime & & -1.98 & -0.26 & 0.31 & 1.79 & 8.48 & 61.61 & 73.46 & 0.54 & -3.14 & 7.41 \\
\hline Full Sample & \multirow{3}{*}{$\begin{array}{r}\text { three periods of } \\
\text { high volatility }\end{array}$} & 0.88 & -1.96 & 0.81 & 3.98 & 8.13 & 60.61 & 53.86 & 0.52 & -257 & 6.32 \\
\hline Low Volatility Regime & & 1.17 & -0.67 & 0.03 & 3.92 & 8.14 & 61.69 & 52.72 & 0.52 & -1.18 & 3.63 \\
\hline High Volatility Regime & & 0.69 & -2.82 & 1.32 & 4.02 & 8.12 & 59.89 & 54.63 & 0.52 & -3.27 & 8.12 \\
\hline Full Sample & \multirow{3}{*}{$\begin{array}{r}\text { four/five periods of } \\
\text { high volatility }\end{array}$} & -0.17 & -233 & 154 & 6.08 & 8.03 & 59.69 & 81.88 & 0.45 & -10.83 & 1186 \\
\hline Low Volatility Regime* & & -0.94 & -5.64 & 1.64 & 5.88 & 8.44 & 66.45 & 117.62 & 0.39 & -15.23 & 5.88 \\
\hline High Volatility Regime & & -0.11 & -2.10 & 1.53 & 6.09 & 8.00 & 59.20 & 79.33 & 0.46 & -10.28 & 12.32 \\
\hline
\end{tabular}

* Only one observation available.

Notes: Observations are separated into low and high volatility regimes using a threshold value for the volatility of real GDP growth of 5.35 percent. This estimate of volatility was obtained from the regression reported in Table 2, column 4 . Income and life expectancy are initial period values and openness is the period average. Fiscal balance however continues to be measured using an average for the entire sample period and institutional quality is measured around 1985. 
Table 7. Current Account Growth Relationship in Countries by Incidence of High Volatility

\begin{tabular}{|c|c|c|c|c|c|c|c|c|c|c|c|c|}
\hline \multicolumn{13}{|c|}{ Dependent Variable: Annual Growth Rates 1980 to 2003} \\
\hline & \multicolumn{3}{|c|}{ O Periods High Volatility } & \multicolumn{3}{|c|}{ O or 1 Periods of High Volatility } & \multicolumn{3}{|c|}{0,1 , or 2 Periods of High Volatility } & \multicolumn{3}{|c|}{$0,1,2$, or 3 Periods of High Volatility } \\
\hline & \multirow{2}{*}{$\begin{array}{c}\text { OLS } \\
(7-1)\end{array}$} & \multicolumn{2}{|c|}{ MaximumLikelihood } & \multirow{2}{*}{$\begin{array}{r}\text { OLS } \\
(7-4)\end{array}$} & \multicolumn{2}{|c|}{ MaximumLikelihood } & \multirow{2}{*}{$\begin{array}{r}\text { OLS } \\
(7-7)\end{array}$} & \multicolumn{2}{|c|}{ MaximumLikelihood } & \multirow{2}{*}{$\begin{array}{r}\text { OLs } \\
(7-10)\end{array}$} & \multicolumn{2}{|c|}{ MaximumLikelihood } \\
\hline & & $(7-2)$ & $(7-3)$ & & $(7-5)$ & $(7-6)$ & & $(7-8)$ & $(7-9)$ & & $(7-11)$ & $(7-12)$ \\
\hline \multirow[t]{2}{*}{ Current Account Balance } & -0.099 & -0.111 & -0.097 & 0.001 & -0.083 & -0.095 & -0.012 & -0.087 & -0.109 & 0.030 & -0.072 & -0.092 \\
\hline & $-(2.01)$ & $-(3.45)$ & $-(2.60)$ & $(0.02)$ & $-(3.01)$ & $-(3.52)$ & $-(0.22)$ & $-(2.66)$ & $-(4.24)$ & $(0.67)$ & $-(2.11)$ & $-(3.54)$ \\
\hline \multirow[t]{2}{*}{ Initial Income } & -2.289 & -2.578 & -2.707 & -1.801 & -1.931 & -2.193 & -2.155 & -2.062 & -2.261 & -2.076 & -1.930 & -2.188 \\
\hline & $-(4.78)$ & $-(5.41)$ & $-(5.14)$ & $-(2.53)$ & $-(2.32)$ & $-(2.75)$ & $-(3.32)$ & $-(2.74)$ & $-(2.82)$ & $-(3.89)$ & $-(2.62)$ & $-(2.80)$ \\
\hline \multirow[t]{2}{*}{ Initial Life Expectancy } & 0.091 & 0.084 & 0.116 & 0.087 & 0.071 & 0.094 & 0.132 & 0.114 & 0.128 & 0.127 & 0.107 & 0.118 \\
\hline & (2.97) & $(2.87)$ & (4.31) & (2.09) & (1.14) & (2.01) & (2.80) & (2.10) & (2.63) & (2.96) & (2.01) & (2.26) \\
\hline \multirow[t]{2}{*}{ Openness } & 0.017 & 0.023 & 0.021 & 0.011 & 0.016 & 0.016 & 0.012 & 0.016 & 0.016 & 0.013 & 0.015 & 0.016 \\
\hline & (6.29) & (6.07) & (6.44) & (2.66) & (4.51) & (5.43) & (2.98) & (4.43) & (5.52) & (3.12) & (4.69) & (5.48) \\
\hline \multirow[t]{2}{*}{ Institutional Quality } & 9.716 & 11.771 & 11.591 & 9.470 & 10.342 & 10.995 & 9.290 & 9.871 & 10.435 & 8.850 & 9.639 & 10.462 \\
\hline & (5.79) & (19.00) & (10.60) & (3.71) & (6.76) & $(7.27)$ & (3.83) & (5.02) & $(5.77)$ & (4.50) & (4.73) & $(5.66)$ \\
\hline \multirow[t]{2}{*}{ Fiscal Balance } & -0.053 & -0.078 & -0.075 & -0.011 & -0.075 & -0.068 & 0.004 & -0.086 & -0.091 & 0.048 & -0.073 & -0.076 \\
\hline & $-(0.76)$ & $-(1.41)$ & $-(1.46)$ & $-(0.14)$ & $-(1.12)$ & $-(1.07)$ & $(0.06)$ & $-(1.37)$ & $-(1.49)$ & $(0.63)$ & $-(1.35)$ & $-(1.50)$ \\
\hline Number of Countries & 26 & 26 & 26 & 41 & 41 & 41 & 48 & 48 & 48 & 58 & 58 & 58 \\
\hline Number of Observations & 604 & 604 & 604 & 959 & 959 & 959 & 1117 & 1117 & 1117 & 1357 & 1357 & 1357 \\
\hline
\end{tabular}

Notes: The dependent variable in each case is the annual growth rate of real GDP from 1980 to 2003 for each country in our sample however the covariates are sample-period averages and initial period-values of our controls. Income and life expectancy are initial period values and openness is the period average. Fiscal balance however continues to be measured using an average for the entire sample period and institutional quality is measured around 1985. Specifications (7-3), (7-6), (7-9), and (7-12) include time-period dummies (coefficients not reported). The numbers in parentheses below the coefficients are t-statistics where we make allowance for within country cluster dependence, by adjusting the standard errors using the Rogers (1993) approach. Each regression was estimated using maximum likelihood. 


\section{Table 8. Panel Regressions}

\begin{tabular}{|l|r|r|r|r|r|}
\hline \multicolumn{3}{|c|}{ Dependent Variable: Average Growth Rate, 1980 to 1984; 1985 to 1989; 1990 to 1994; 1995 to } \\
\hline & \multicolumn{2}{|c|}{ Low Regime } & \multicolumn{2}{|c|}{ High Regime } \\
\hline & Fixed Effects & Arellano-Bover & Fixed Effects & Arellano-Bover \\
\hline Current Account & $(8-1)$ & $(8-2)$ & $(8-3)$ & $(8-4)$ \\
\hline & -0.112 & -0.184 & 0.251 & 0.000 \\
\hline Initial Income & $-(2.99)$ & $-(2.33)$ & $(2.19)$ & $(0.00)$ \\
\hline & -1.986 & -0.871 & -6.880 & -6.247 \\
\hline Initial Life Expectancy & $-(2.74)$ & $-(1.03)$ & $-(1.76)$ & $-(2.08)$ \\
\hline & 0.051 & 0.097 & 0.342 & 0.638 \\
\hline Openness & $(0.95)$ & $(1.02)$ & $(1.47)$ & $(4.74)$ \\
\hline & 0.017 & 0.029 & 0.041 & -0.052 \\
\hline Number of Countries & $(2.76)$ & $(3.66)$ & $(0.80)$ & $-(1.45)$ \\
\hline Number of Observations & 59 & 59 & & 35 \\
\hline First order serial correlation & 225 & 225 & & 73 \\
\hline Second order serial correlation & & $(0.00)$ & & 73 \\
\hline Sargan test & & $(0.77)$ & & $(0.29)$ \\
\hline Number of Instruments & & $(0.23)$ & & $(0.18)$ \\
\hline
\end{tabular}

Notes: The dependent variable is the average growth rate over the following non-overlapping intervals: 1980-84, 1985-89, 1990-94, 1995-99, and 2000-03. Income and life expectancy are initial period values and openness is the period average. Each specification also includes time dummies (coefficients not reported). The low regime includes all observations for which volatility of growth was less than or equal to 5.35 percent; the high volatility regime includes all observations for which volatility exceeded this figure. The numbers in parentheses below the coefficients are robust tstatistics. 
Table 9. Breakdown by Type of Flow

\begin{tabular}{|c|c|c|c|c|c|c|c|c|}
\hline \multicolumn{9}{|c|}{ Dependent Variable: Average Growth Rate, 1980 to 1984; 1985 to 1989; 1990 to 1994; 1995 to 2000; 2000 to 2003} \\
\hline 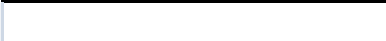 & \multicolumn{4}{|c|}{ Low Regime } & \multicolumn{4}{|c|}{ High Regime } \\
\hline & \multicolumn{2}{|c|}{ Fixed Effects Arellano-Bover } & \multicolumn{2}{|c|}{ Fixed Effects Arellano-Bover } & \multicolumn{2}{|c|}{ Fixed Effects Arellano-Bover } & \multicolumn{2}{|c|}{ Fixed Effects ellano-Bover } \\
\hline & $(9-1)$ & $(9-2)$ & $(9-3)$ & $(9-4)$ & $(9-5)$ & $(9-6)$ & $(9-7)$ & $(9-8)$ \\
\hline \multirow[t]{2}{*}{ Private Flows } & 0.098 & 0.242 & 0.064 & 0.144 & 0.193 & 0.166 & 0.003 & -0.007 \\
\hline & $(2.54)$ & $(2.76)$ & (1.63) & (2.29) & (0.98) & $(1.55)$ & $(0.02)$ & $-(0.05)$ \\
\hline \multirow[t]{2}{*}{ Foreign Aid } & -0.099 & -0.113 & -0.086 & -0.072 & -0.563 & -0.210 & -0.482 & 0.134 \\
\hline & $-(1.09)$ & $-(0.74)$ & $-(0.96)$ & $-(0.67)$ & $-(1.68)$ & $-(0.64)$ & $-(1.15)$ & (0.48) \\
\hline \multirow[t]{2}{*}{ Initial Income } & -2.000 & -0.413 & -3.044 & -1.593 & -6.037 & -8.258 & -1.671 & -7.110 \\
\hline & $-(2.66)$ & $-(0.53)$ & $-(2.83)$ & $-(2.82)$ & $-(1.53)$ & $-(3.77)$ & $-(0.37)$ & $-(6.48)$ \\
\hline \multirow[t]{2}{*}{ Initial Life Expectancy } & 0.044 & 0.011 & 0.027 & 0.085 & 0.333 & 0.618 & 0.525 & 0.690 \\
\hline & $(0.78)$ & (0.16) & $(0.48)$ & $(1.80)$ & (1.26) & $(6.80)$ & (1.95) & $(5.55)$ \\
\hline \multirow[t]{2}{*}{ Openness } & 0.016 & 0.030 & 0.007 & 0.011 & 0.037 & -0.085 & 0.096 & 0.025 \\
\hline & $(2.45)$ & $(2.86)$ & $(0.92)$ & $(2.02)$ & $(0.73)$ & $-(2.73)$ & $(1.70)$ & (1.19) \\
\hline \multirow[t]{2}{*}{ Population Growth } & & & 0.408 & -1.066 & & & -2.921 & -1.696 \\
\hline & & & $(1.26)$ & $-(2.64)$ & & & $-(1.75)$ & $-(1.90)$ \\
\hline \multirow[t]{2}{*}{ Financial Development } & & & 0.008 & 0.024 & & & -0.041 & 0.015 \\
\hline & & & $(0.70)$ & $(2.87)$ & & & $-(0.36)$ & $(0.21)$ \\
\hline \multirow[t]{2}{*}{ Financial Integration } & & & -0.004 & -0.001 & & & 0.008 & -0.027 \\
\hline & & & $-(1.48)$ & $-(0.52)$ & & & $(0.26)$ & $-(2.40)$ \\
\hline Number of Countries & 58 & 58 & 54 & 54 & 35 & 35 & 32 & 32 \\
\hline Number of Observations & 216 & 216 & 194 & 194 & 73 & 73 & 64 & 64 \\
\hline R-squared (within) & $(0.20)$ & & $(0.24)$ & & (0.35) & & $(0.42)$ & \\
\hline First order serial correlation & & $(0.00)$ & & $(0.00)$ & & $(0.34)$ & & $(0.63)$ \\
\hline Second order serial correlation & & $(0.85)$ & & $(0.17)$ & & $(0.21)$ & & $(0.19)$ \\
\hline Hansen test & & $(0.57)$ & & $(1.00)$ & & $(1.00)$ & & $(1.00)$ \\
\hline Number of Instruments & & 50 & & 77 & & 29 & & 29 \\
\hline
\end{tabular}

Notes: The dependent variable is the average growth rate over the following non-overlapping intervals: 1980-84, 1985-89, 1990-94, 1995-99, and 2000-03. Income and life expectancy are initial period values. Flows, openness, population growth, financial development and financial integration are period averages. Each specification also includes time dummies (coefficients not reported). The low regime includes all observations for which volatility of growth was less than or equal to 5.35 percent; the high volatility regime includes all observations for which volatility exceeded this figure. The numbers in parentheses below the coefficients are robust t-statistics. In the bottom of the table the numbers in parentheses are p-values. 
Table 10. Determinants of Volatility

\begin{tabular}{|c|c|c|c|c|c|c|}
\hline \multicolumn{4}{|l|}{ Dependent Variable: Volatility 1980 to 2003} & \multicolumn{3}{|c|}{ Dependent Variable: Volatility Five } \\
\hline & (1) & (2) & (3) & $(4)$ & $(5)$ & (6) \\
\hline \multirow[t]{2}{*}{ Standard Deviation of Predicted Growth } & 1.469 & & 1.128 & 1.024 & 1.009 & 1.036 \\
\hline & $(7.92)$ & & $(6.79)$ & $(10.46)$ & $(9.39)$ & $(8.73)$ \\
\hline \multirow[t]{2}{*}{ Initial Population } & & -0.416 & -0.103 & & & \\
\hline & & $-(2.15)$ & $-(1.03)$ & & & \\
\hline \multirow[t]{2}{*}{ Percent of Land Area $100 \mathrm{~km}$ from Coast } & & -0.117 & -0.044 & & & \\
\hline & & $-(2.66)$ & $-(1.87)$ & & & \\
\hline \multirow[t]{2}{*}{ Percent of Land Area $100 \mathrm{~km}$ from Coast ${ }^{2}$} & & 0.001 & 0.000 & & & \\
\hline & & (2.69) & $(1.70)$ & & & \\
\hline \multirow[t]{2}{*}{ Landlock } & & -1.012 & -0.002 & & & \\
\hline & & $-(0.96)$ & $(0.00)$ & & & \\
\hline \multirow[t]{2}{*}{ Volatility of Terms of Trade } & & 0.056 & 0.031 & & & \\
\hline & & $(0.97)$ & $(0.83)$ & & & \\
\hline \multirow[t]{2}{*}{ War } & & -7.006 & -2.738 & & & \\
\hline & & $-(3.35)$ & $-(2.10)$ & & & \\
\hline \multirow[t]{2}{*}{ Ethnic Fractionalization } & & -0.004 & 0.006 & & & \\
\hline & & $-(0.29)$ & $(0.69)$ & & & \\
\hline \multirow[t]{2}{*}{ Ethnic Fractionalization*War } & & 0.126 & 0.047 & & & \\
\hline & & (3.14) & $(1.64)$ & & & \\
\hline \multirow[t]{2}{*}{ Institutional Quality } & & 1.277 & -0.735 & & & \\
\hline & & $(0.51)$ & $-(0.44)$ & & & \\
\hline \multirow[t]{2}{*}{ Government type } & & -0.103 & -0.054 & & & \\
\hline & & $-(2.19)$ & $-(1.78)$ & & & \\
\hline \multirow[t]{2}{*}{ Current Account } & & & & & -0.061 & \\
\hline & & & & & $-(0.93)$ & \\
\hline \multirow[t]{2}{*}{ Private Flows } & & & & & & -0.029 \\
\hline & & & & & & $-(0.64)$ \\
\hline \multirow[t]{2}{*}{ Official Flows } & & & & & & 0.031 \\
\hline & & & & & & $(0.30)$ \\
\hline Number of observations & 61 & 53 & 53 & 298 & 298 & 266 \\
\hline Number of Countries & 61 & 53 & 53 & 61 & 61 & 54 \\
\hline R-squared within & & & & 0.25 & 0.26 & 0.26 \\
\hline R-squared between & & & & 0.74 & 0.73 & 0.73 \\
\hline R-squared & 0.76 & 0.45 & 0.81 & 0.50 & 0.50 & 0.50 \\
\hline
\end{tabular}

Notes: In columns 1 to 3 the dependent variable is an estimate of the volatility of growth between 1980 and 2004 obtained from Table 1, column 6. Population, institutional quality and government type are 1980 values. The volatility of terms of trade is the standard deviation of terms of trade shocks between 1980 and 2003. All other variables are country-specific. In columns 4 to 8 , the dependent variable is our estimate of growth volatility over the following non-overlapping intervals: $1980-84$, 1985-89, 1990-94, 1995-99, and 2000-03. The current account deficit and private and official flows are averages over the same periods. The specifications in columns (4) to (8) include time dummies (coefficients not reported). The numbers in parentheses below the coefficients are t-statistics where we make allowance for within country cluster dependence, by adjusting the standard errors using the Rogers (1993) approach. 
Figure 1. The Paradox of Capital

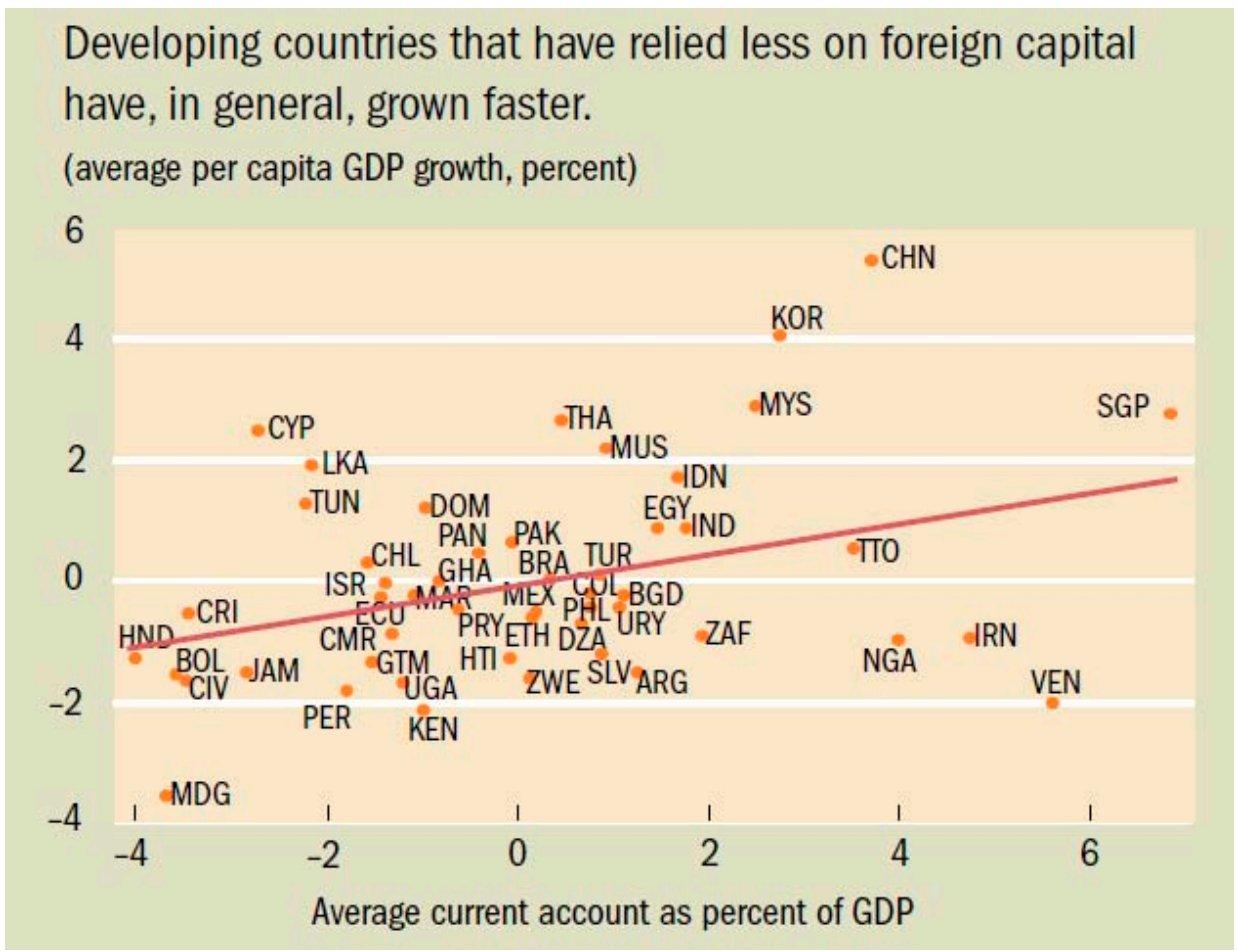

Source: Prasad, Rajan, and Subramaniam (2007). 
Figure 2. Current Account and Growth: Volatility Regimes

Low Volatility Regime

Cross-Sectional Regression

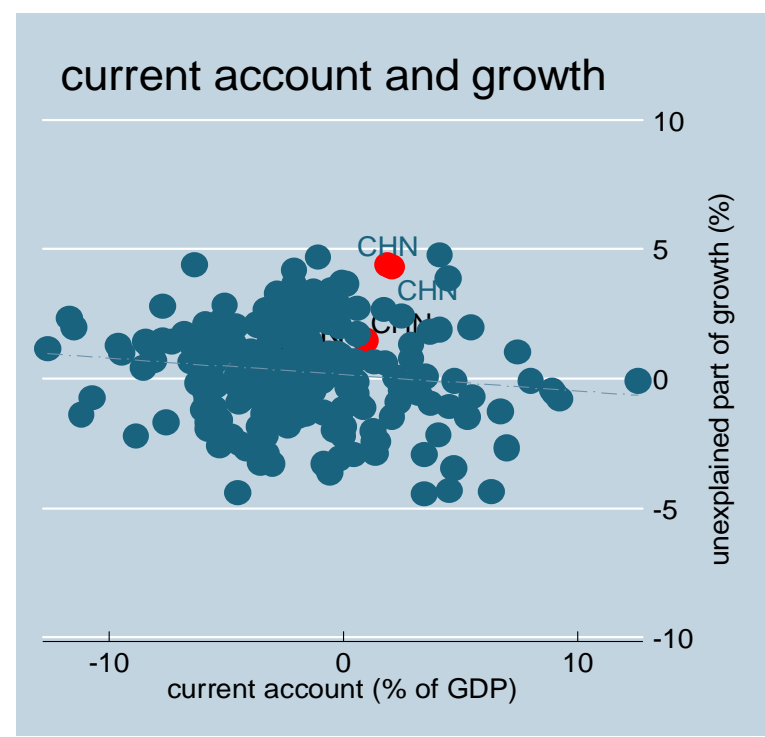

Fixed Effects Regression

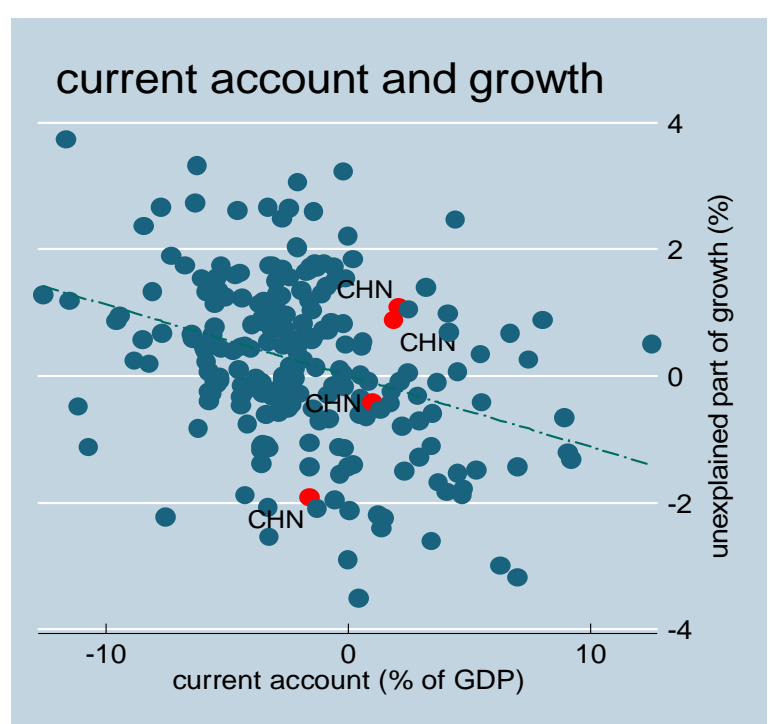

High Volatility Regime

Cross-Sectional Regression

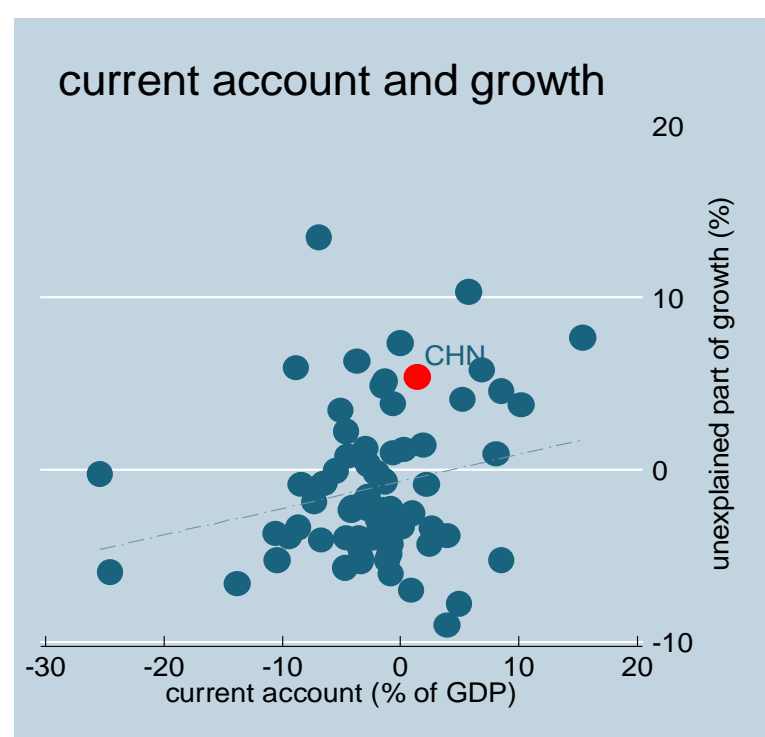

Fixed Effects Regression

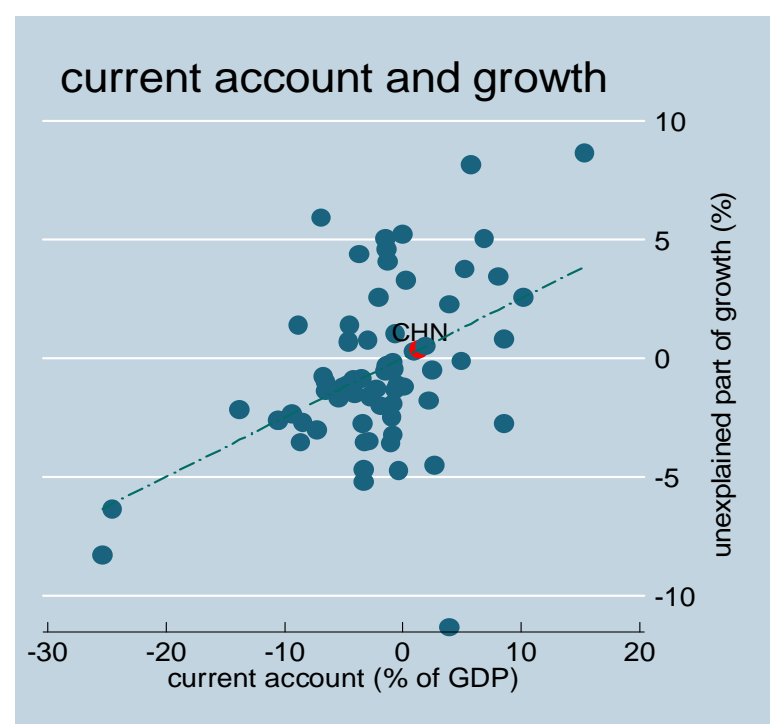


Figure 3a. Number of Times Countries Experienced High Growth Volatility

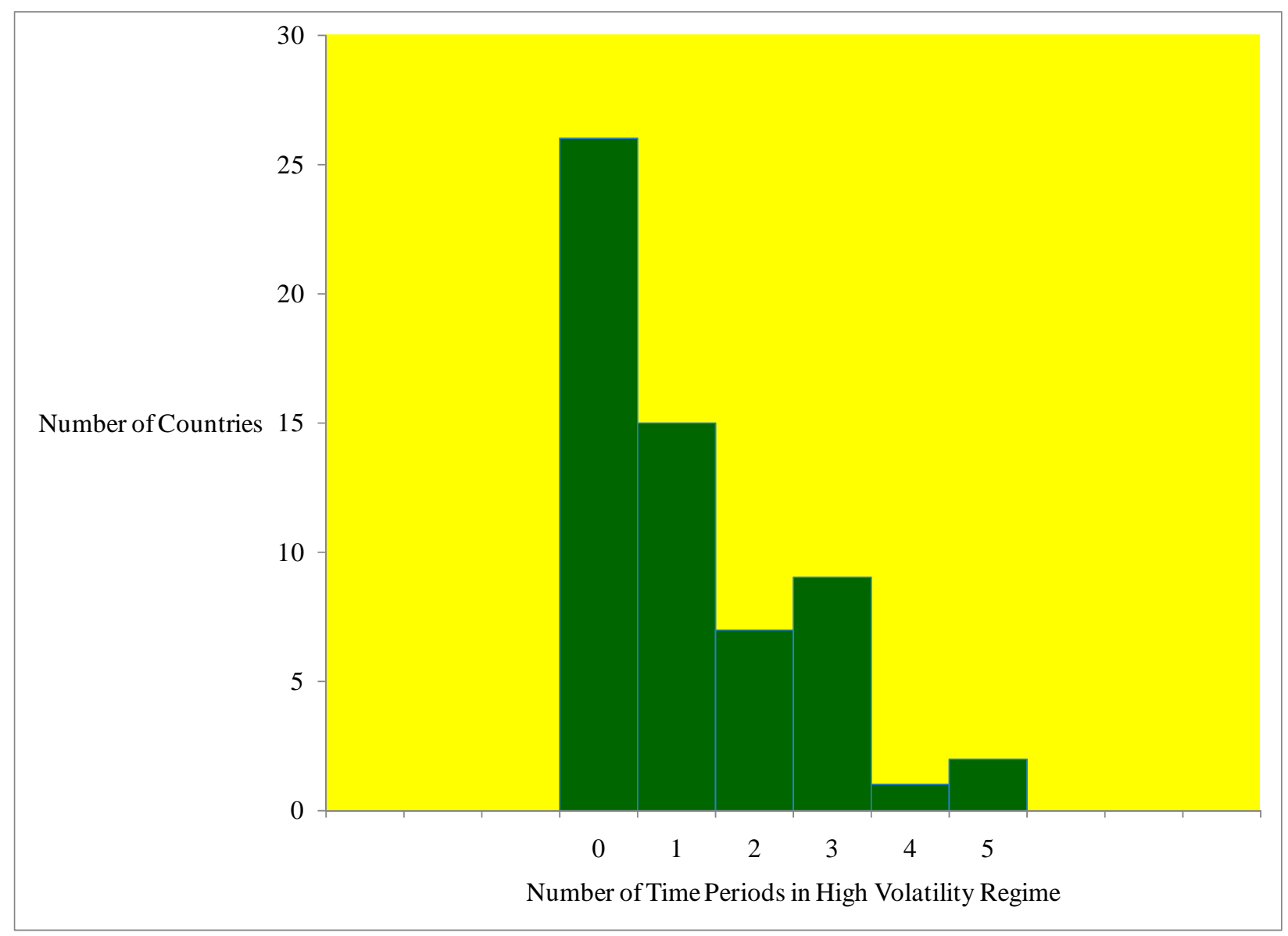


Figure 3b. Number of Times Countries Experienced High Growth Volatility by Time Period

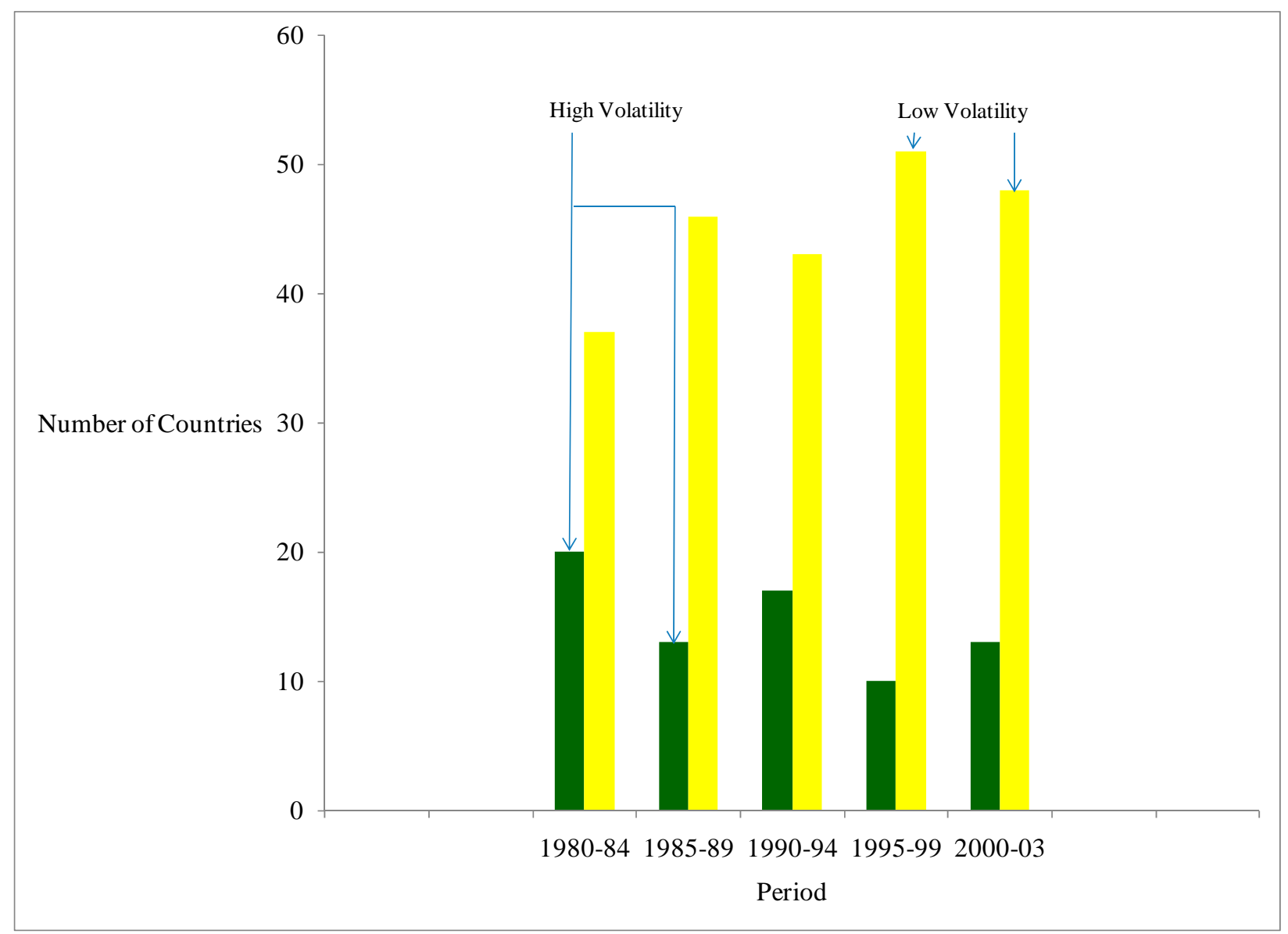

